\title{
Article \\ Effects of Trace Amounts of Mn, Zr and Sc on the Recrystallization and Corrosion Resistance of Al-5Mg Alloys
}

\author{
Sheng-Long Lee ${ }^{1,2, *}$, Yang-Chun Chiu ${ }^{1,3}$, Tse-An Pan ${ }^{1}$ and Mien-Chung Chen ${ }^{1}$ \\ 1 Institute of Materials Science and Engineering, National Central University, Jhongli 32001, Taiwan; \\ albert77918@gmail.com (Y.-C.C.); peterpan.ck@gmail.com (T.-A.P.); mianzhongchen@gmail.com (M.-C.C.) \\ 2 Department of Mechanical Engineering, National Central University, Jhongli 32001, Taiwan \\ 3 IPEBG, Foxconn Technology Group, Shenzhen 518109, China \\ * Correspondence: shenglon@cc.ncu.edu.tw
}

Citation: Lee, S.-L.; Chiu, Y.-C.; Pan, T.-A.; Chen, M.-C. Effects of Trace Amounts of Mn, $\mathrm{Zr}$ and Sc on the Recrystallization and Corrosion Resistance of Al-5Mg Alloys. Crystals 2021, 11, 926. https://doi.org/ 10.3390/cryst11080926

Academic Editors: Adam Zieliński, Grzegorz Golański and Marek Sroka

Received: 10 July 2021

Accepted: 4 August 2021

Published: 10 August 2021

Publisher's Note: MDPI stays neutral with regard to jurisdictional claims in published maps and institutional affiliations.

\begin{abstract}
This study aimed to explore the effects of trace amounts of $\mathrm{Mn}, \mathrm{Zr}$, and Sc on the recrystallization behavior and corrosion resistance of Al-5Mg alloys after process annealing by means of alloy design and microstructure analysis of electron backscatter diffraction (EBSD), electron microprobe (EPMA), and electron microscopes (TEM and SEM). The main objective was to obtain alloys with better corrosion resistance. The results show that the fine $\mathrm{Al}_{3} \mathrm{Zr}$ and $\mathrm{Al}_{3} \mathrm{Sc}$ precipitated particles were both superior to the $\mathrm{MnAl}_{6}$ particles in inhibiting grain and sub-grain boundary migrations. Therefore, the Zr-containing and Sc-containing alloys were better than the Mn-containing alloy in inhibiting recrystallization. For further comparison, the thermal stability of the $\mathrm{Al}_{3} \mathrm{Sc}$ particles was better than that of the $\mathrm{Al}_{3} \mathrm{Zr}$ particles, so the Sc-containing alloy at the high temperature above $350{ }^{\circ} \mathrm{C}$ inhibited grain growth better than the $\mathrm{Zr}$-containing alloy. During the recovery stage of the alloy in the recrystallization process, the $\beta-\mathrm{Mg}_{2} \mathrm{Al}_{3}$ phase precipitated on the sub-grain boundary, thus reducing the occurrence of intergranular corrosion. However, in the initial stage of recrystallization, the $\beta-\mathrm{Mg}_{2} \mathrm{Al}_{3}$ phase continuously precipitated on the grain boundary, causing obvious intergranular corrosion. For the Sc-containing alloy, because there was no obvious grain growth stage, the $\beta-\mathrm{Mg}_{2} \mathrm{Al}_{3}$ phase continuously precipitated on the grain boundary, and thereby intergranular corrosion occurred. Therefore, its corrosion resistance was greatly reduced. By contrast, for the alloy containing $\mathrm{Mn}$ or $\mathrm{Zr}$, because of obvious grain growth, magnesium atoms aggregated. As a result, the $\beta-\mathrm{Mg}_{2} \mathrm{Al}_{3}$ phase discontinuously precipitated on the grain boundary. The corrosion morphology was local pitting corrosion rather than intergranular corrosion, and thus the corrosion resistance of the alloy was enhanced. As a novelty, this study clearly observed the sensitized precipitation and corrosion morphology of the $\beta-\mathrm{Mg}_{2} \mathrm{Al}_{3}$ phase of $\mathrm{Al}-5 \mathrm{Mg}$ alloy under different recrystallization methods. This will be of benefit to the design of anti-corrosion measures for the future manufacturing and application of Al-5Mg alloy.
\end{abstract}

Keywords: Al-Mg alloy; microstructure; process annealing; recrystallization; corrosion resistance

\section{Introduction}

The 5000 series aluminum-magnesium alloy with the magnesium atom as the main alloying element is a forged non-heat-treated aluminum alloy with good corrosion resistance and weldability [1]. It has been widely used in ship structures, vehicle skeletons, storage tanks, and other materials [1]. The Al-Mg alloy has good solid solution strengthening and processing strengthening characteristics, and its strength increases with the increasing content of magnesium [1]. The shapes of Al-Mg alloys are mainly produced by cold working (such as H18, H38) in the industry. Because of the high amount of cold working, the $\beta-\mathrm{Mg}_{2} \mathrm{Al}_{3}$ phase of the alloy starts to precipitate along the sub-grain boundary, grain boundary and dislocation with high energy when the working temperature is $40 \sim 50{ }^{\circ} \mathrm{C}[2,3]$. This phenomenon is also called sensitization [3]. The more the magnesium 
content and the longer the exposure time increase, the higher the density of the phase precipitation becomes $[4,5]$. Because the potential of the phase corrosion $(-1.24 \mathrm{~V})$ is lower than that of the aluminum matrix $(-0.87 \mathrm{~V})[1]$, the $\beta-\mathrm{Mg}_{2} \mathrm{Al}_{3}$ phase becomes the sacrificial anode in a corrosive environment and is preferably corroded. When the phase precipitates on the grain boundary more densely and tends to be continuous in the form of a network, the 5000 series $\mathrm{Al}-\mathrm{Mg}$ alloy, which is originally corrosion resistant, becomes sensitive to the corrosive environment. The precipitated phase on the grain boundary causes serious intergranular corrosion $[1,3,6]$. In the subsequent storage, transportation, and molding, the alloy is subject to serious loss. Therefore, in the industry, the processed shapes need to be subjected to stabilizing treatment or process annealing [7]. However, the annealing temperature of the process has a significant impact on the recrystallization and corrosion properties. When the process annealing is lower than $350{ }^{\circ} \mathrm{C}$, the corrosion resistance of the alloy will be greatly reduced $[7,8]$. On the contrary, when the annealing temperature is too high, the recrystallized grains will start to grow abnormally and have an adverse effect on the subsequent formability $[9,10]$. Methods to achieve the best combination between the corrosion properties and microstructure of the $\mathrm{Al}-\mathrm{Mg}$ alloy shapes are worthy of research.

In addition, in the new additive manufacturing [11] and welding [12], the heat-affected zone (HAZ) affects the recrystallization behavior of the alloy and the precipitation of $\beta-\mathrm{Mg}_{2} \mathrm{Al}_{3}$ phase. It has become a major research topic. How to improve the new process to obtain stable mechanical properties and corrosion resistance is also worthy of research.

Because the partition ratio of either $\mathrm{Zr}$ or Sc transition element in the alloy is greater than 1 , the peritectic reaction is prone to occur during the casting process, causing these elements to segregate in the grains [1]. During the homogenization heat treatment, dispersed phase grains such as $\mathrm{Al}_{3} \mathrm{Zr}$ and $\mathrm{Al}_{3} \mathrm{Sc}$ will be precipitated in the crystal grains. These dispersed phase grains are dense and fine coherent precipitates with high temperature thermal stability $[13,14]$, which can effectively inhibit alloy dislocation and grain boundary migration. Compared with the traditional aluminum alloy with Mn added, a trace amount of $\mathrm{Zr}$ or Sc in the aluminum alloy can not only increase the recrystallization temperature of the alloy [1,14], but also significantly inhibit the growth of grains [15-17].

In this study, the effects of different recrystallizations on the microstructure and corrosion properties of 5000 series Al-Mg alloys were evaluated by adding trace amounts of $\mathrm{Mn}$, $\mathrm{Zr}$, and Sc after process annealing at different temperatures. This study clearly observed the sensitized precipitation and corrosion morphology of the $\beta-\mathrm{Mg}_{2} \mathrm{Al}_{3}$ phase of $\mathrm{Al}-5 \mathrm{Mg}$ alloy under different recrystallization methods. It is helpful for further understanding the development of alloy corrosion to obtain alloys with excellent corrosion resistance, and for the future application of 5000 series Al-Mg alloys [4,18-20].

\section{Materials and Methods}

After the pure aluminum ingot $(99.7 \%)$ was melted in a resistance crucible furnace at $750{ }^{\circ} \mathrm{C}$, pure $\mathrm{Mg}(99.9 \%), \mathrm{Al}-75 \mathrm{Mn}$ master alloy, $\mathrm{Al}-10 \mathrm{Zr}$ master alloy, and $\mathrm{Al}-2 \mathrm{Sc}$ master alloy were added as planned. After dissolving and stirring uniformly, it was degassed with argon gas for $20 \mathrm{~min}$, and left to stand for $10 \mathrm{~min}$. After the slag was removed, the solution was cast in a preheated $\left(300^{\circ} \mathrm{C}\right.$ ) metal mold (size: $\left.125 \times 100 \times 25 \mathrm{~mm}^{3}\right)$. The OES (spectrometer) analysis showed its composition as listed in Table 1 . There were three kinds of alloys tested, which are marked as alloy $\mathrm{A}(0.1 \mathrm{Mn}$ : commercial AA5356), alloy B(0.1Zr), and alloy $\mathrm{C}(0.05 \mathrm{Sc})$.

After homogenization treatment at $470{ }^{\circ} \mathrm{C}$ for $12 \mathrm{~h}$, the cast alloys were hot rolled at $400{ }^{\circ} \mathrm{C}$, then underwent $35 \%$ hot working (processed from a thickness of $20 \mathrm{~mm}$ to $12.5 \mathrm{~mm}$ ), annealing treatment at $450^{\circ} \mathrm{C}$ for $1 \mathrm{~h}$, and $\mathrm{H} 18$ cold rolling processing (processed from a thickness of $12.5 \mathrm{~mm}$ to $3 \mathrm{~mm}$ ). After the processing was completed, the annealing process was carried out at three different temperatures of $250{ }^{\circ} \mathrm{C}, 350{ }^{\circ} \mathrm{C}$, and $450{ }^{\circ} \mathrm{C}$ for $1 \mathrm{~h}$ respectively to explore the recrystallization of the alloys. Subsequently, a sensitization treatment of $150{ }^{\circ} \mathrm{C}$ for $100 \mathrm{~h}$ was applied, and then the alloys were immersed in the nitric acid solution (70 Vol.\%) at $30^{\circ} \mathrm{C}$ for $24 \mathrm{~h}$. Afterwards, the ASTM-G67 nitric acid 
mass loss test (NAMLT) [3] was utilized to measure the degrees of intergranular corrosion sensitization of the alloys. The size of the G67 test bar is $3 \times 6 \times 50 \mathrm{~mm}^{3}$.

Table 1. Analysis of alloy composition ( $w \mathrm{t} \%)$.

\begin{tabular}{cccccccc}
\hline Clloy & Mg & Mn & Zr & Sc & Fe & Si & Al \\
\hline $\mathrm{A}(0.1 \mathrm{Mn})$ & 5.22 & 0.09 & N.D. & N.D. & 0.07 & 0.06 & Rem. \\
\hline $\mathrm{B}(0.1 \mathrm{Zr})$ & 5.10 & N.D. & 0.11 & N.D. & 0.08 & 0.04 & Rem. \\
\hline $\mathrm{C}(0.05 \mathrm{Sc})$ & 5.23 & N.D. & N.D. & 0.05 & 0.08 & 0.03 & Rem. \\
\hline
\end{tabular}

N.D.: Non-detectable; Rem.: Remainder; Com.: Composition.

The polished alloys were anodized with Barker's reagent and etched with phosphoric acid $\left(40 \mathrm{~mL} \mathrm{H}_{3} \mathrm{PO}_{4}+60 \mathrm{~mL} \mathrm{H}_{2} \mathrm{O}\right.$ at $\left.35^{\circ} \mathrm{C}\right)$ solution to make metallographic test pieces. An optical microscope (OM, Olympus BX60M, Japan) and a field emission scanning electron microscope (SEM, FEI-SEM, Nova NanoSEM 230, USA) were used to observe the crystal grains, $\beta$ phase distribution and G67 surface morphology of corrosion. An electron backscatter diffraction (EBSD, JEOL JXA-iHP200F, Japan) was utilized to scan the specimens.

Subsequently, the alloy grain size, aspect ratio, and recrystallization ratio were quantitatively analyzed with a MATLAB ${ }^{\mathrm{TM}}$ (MathWorks, USA) open source toolbox software MTEX to quantitatively analyze the alloy grain size, aspect ratio, and recrystallization ratio. It is defined here that if the grain boundary angle is greater than $15^{\circ}$, it is regarded as a recrystallized grain. The recrystallization rate is defined as the area fraction occupied by recrystallized grains. When the recrystallization rate reaches $90 \%$ it is regarded as complete recrystallization. Aspect ratio is defined as ratio of the minor axis to major axis of the elliptical grain.

The field emission transmission electron microscope (TEM, JEOL JEM-ARM200FTH, Japan) and the high-resolution field emission electron probe microanalyzer (EPMA, JEOL JXA-iHP200F, Japan) were used to observe and analyze the microstructure and composition of the precipitated phases. The equipment used in this study is as shown in Figure 1.
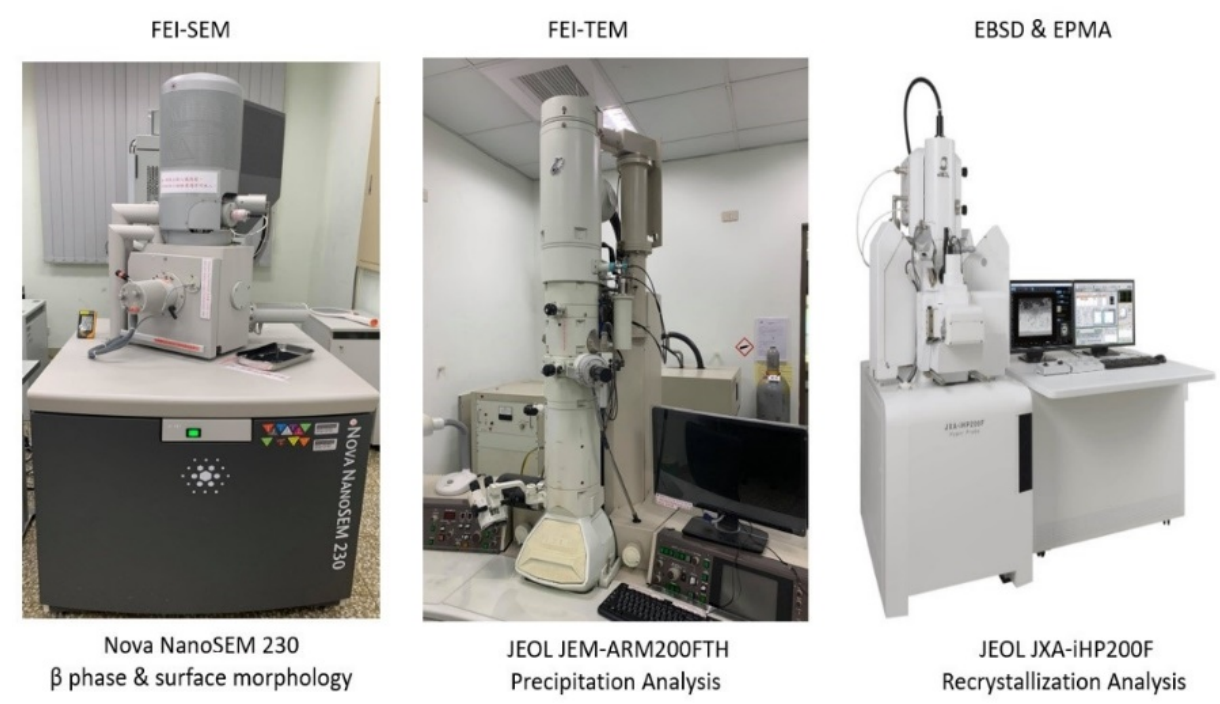

Figure 1. Experimental equipment for $\mathrm{Al}-5 \mathrm{Mg}$ alloy.

\section{Results and Discussion}

\subsection{Microstructure Observation}

\subsubsection{Optical Metallographic Observations}

The casting microstructure of alloy $\mathrm{A}(0.1 \mathrm{Mn})$ containing $\mathrm{Mn}$ is as shown in Figure 2a. The average grain diameter was about $200 \mu \mathrm{m}$. The casting microstructures of alloy $\mathrm{B}(0.1 \mathrm{Zr})$ containing $\mathrm{Zr}$ and alloy $\mathrm{C}(0.05 \mathrm{Sc})$ containing Sc were similar to that of alloy $\mathrm{A}(0.1 \mathrm{Mn})$, 
except that the grains were relatively coarser, about $300 \mu \mathrm{m}$ and $600 \mu \mathrm{m}$ in diameter, as shown in Figure $2 \mathrm{~b}$ and Figure $2 \mathrm{c}$ respectively. This result showed that the heterogeneous nucleation produced by manganese and zirconium significantly refined the grains [21]. The microstructure of $\mathrm{A}(0.1 \mathrm{Mn})$ after $\mathrm{H} 18$ cold rolling is as shown in Figure 2d. It can be observed that after processing, the alloy exhibited a Lamellar rolling structure [22,23]. Its crystal grains were elongated along the rolling direction with fibrous texture. The H18 microstructures of alloy $\mathrm{B}(0.1 \mathrm{Zr})$ and alloy $\mathrm{C}(0.05 \mathrm{Sc})$ were not significantly different from that of alloy $\mathrm{A}(0.1 \mathrm{Mn})$ as shown in Figure $2 \mathrm{e}$ and Figure $2 \mathrm{f}$ respectively.

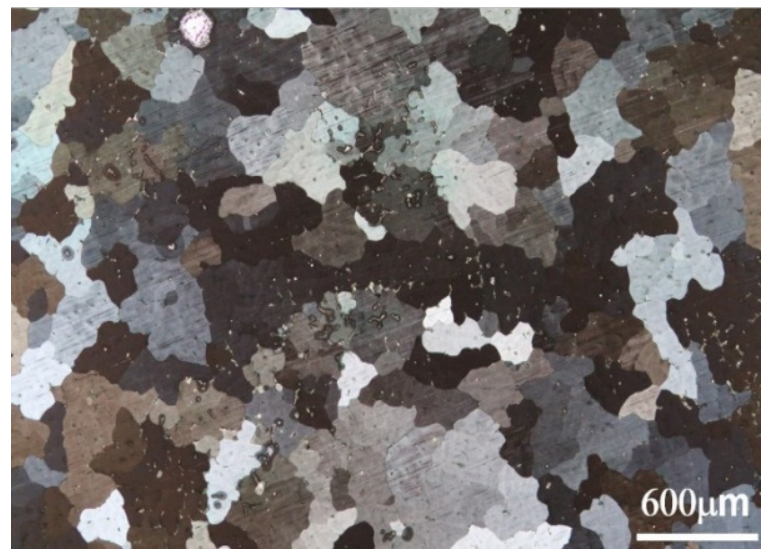

(a)

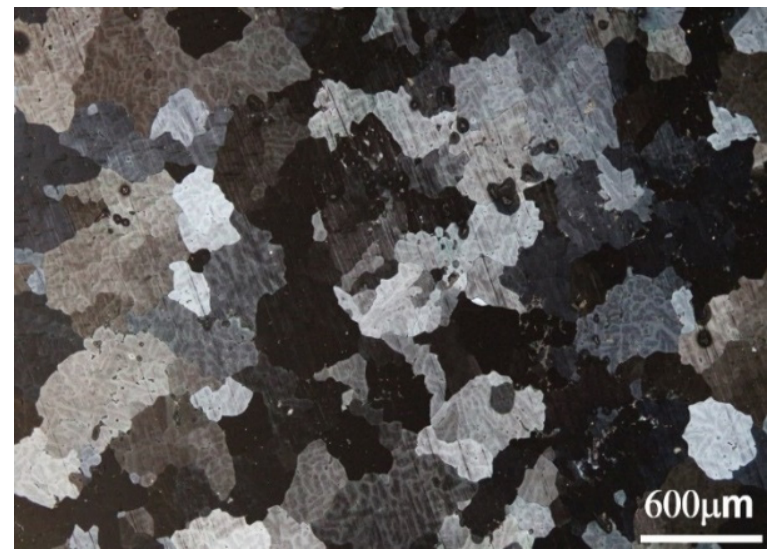

(b)

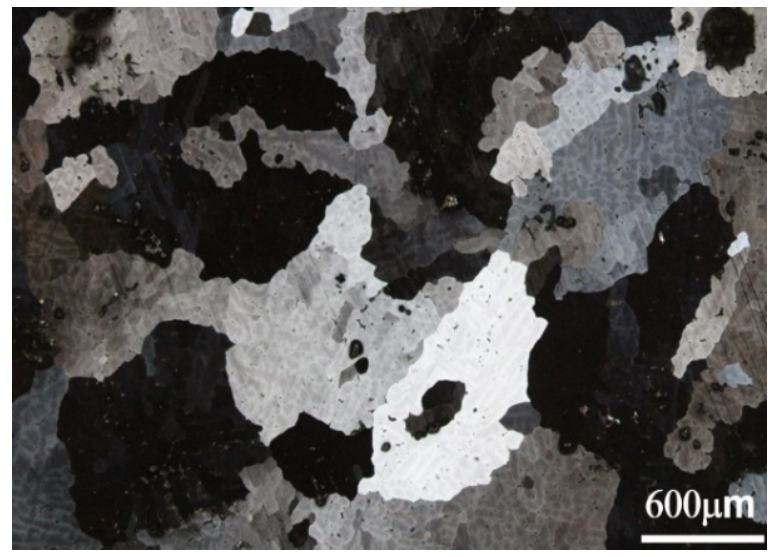

(c)

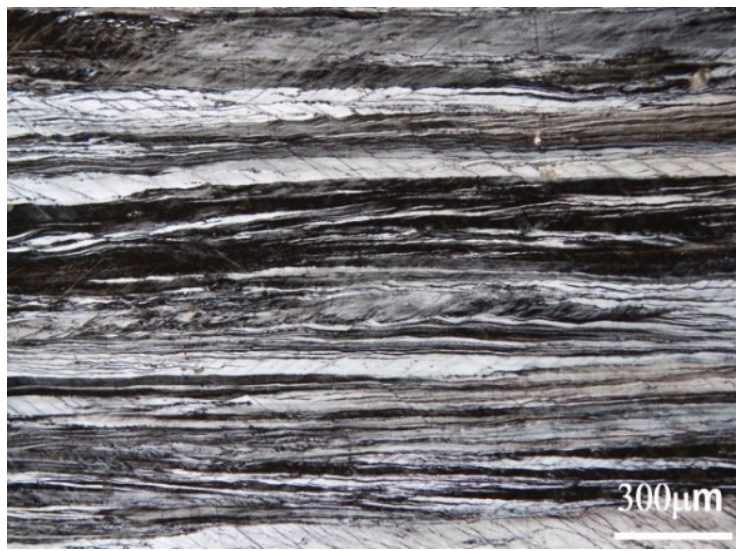

(d)

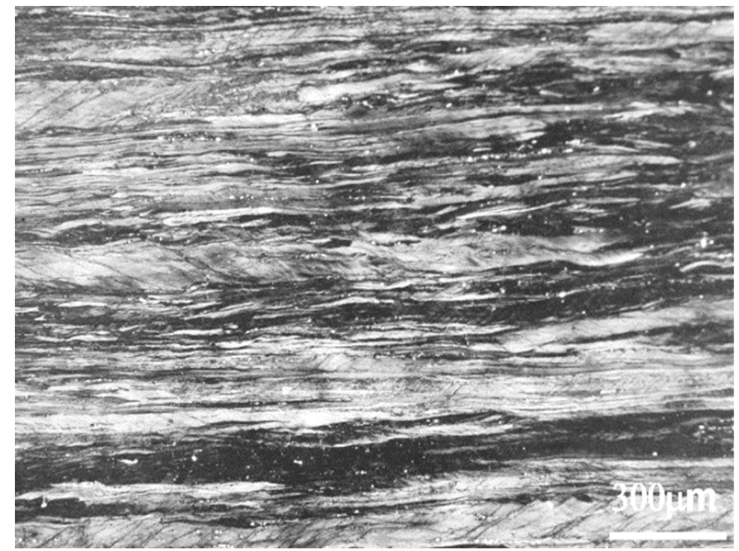

(e)

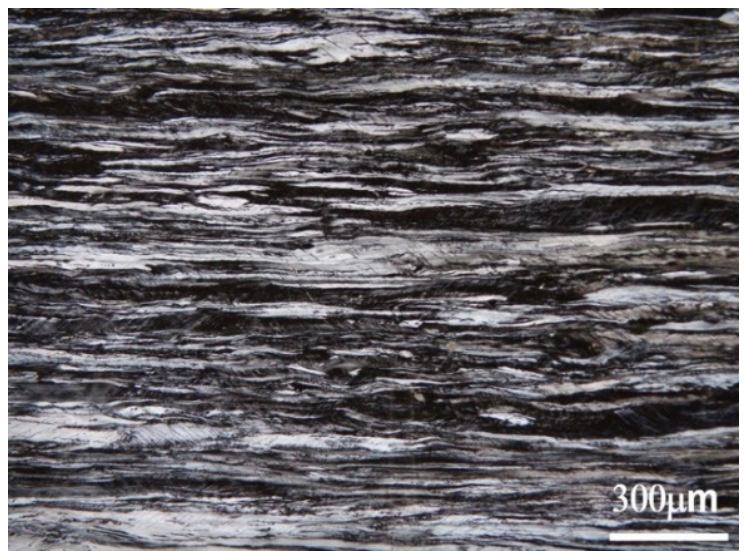

(f)

Figure 2. OM metallography: (a) metallography of as-cast alloy $\mathrm{A}(0.1 \mathrm{Mn}) ;(\mathbf{b})$ metallography of as-cast alloy $\mathrm{B}(0.1 \mathrm{Zr})$; (c) metallography of as-cast alloy $\mathrm{C}(0.05 \mathrm{Sc}) ;(\mathbf{d})$ metallography of $\mathrm{H} 18$ alloy $\mathrm{A}(0.1 \mathrm{Mn})$; (e) metallography of $\mathrm{H} 18$ alloy $\mathrm{B}(0.1 \mathrm{Zr})$; (f) metallography of $\mathrm{H} 18$ alloy $\mathrm{C}(0.05 \mathrm{Sc})$. 


\subsubsection{Recrystallization Analysis}

Alloy $\mathrm{A}(0.1 \mathrm{Mn})$ began to somewhat recrystallized when the annealing temperature of the process was $250^{\circ} \mathrm{C}$, as shown in Figure 3a. By means of EBSD analysis software, Table 2 shows that the recrystallization rate was $28 \%$. However, most of its grain morphology was a textured crystal structure, so the grain size and aspect ratio could not be effectively calculated. As the annealing temperature reached $350{ }^{\circ} \mathrm{C}$, as shown in Figure $3 \mathrm{~b}$, alloy $\mathrm{A}(0.1 \mathrm{Mn})$ was nearly completely recrystallized, and its recrystallization rate was $88.3 \%$. The grain size and aspect ratio were $243.5 \mu \mathrm{m}^{2}$ and 1.44 , respectively. When the process annealing temperature rose to $450{ }^{\circ} \mathrm{C}$, as shown in Figure 3c, the grain size increased to $1037.1 \mu \mathrm{m}^{2}$ and grew by $325.9 \%$. Apparently, the grains of alloy $\mathrm{A}(0.1 \mathrm{Mn})$ grew tremendously. The aspect ratio analysis revealed that the aspect ratio rose to 1.56 and its rate of change was $8.3 \%$, indicating that the grain growth was anisotropic growth.

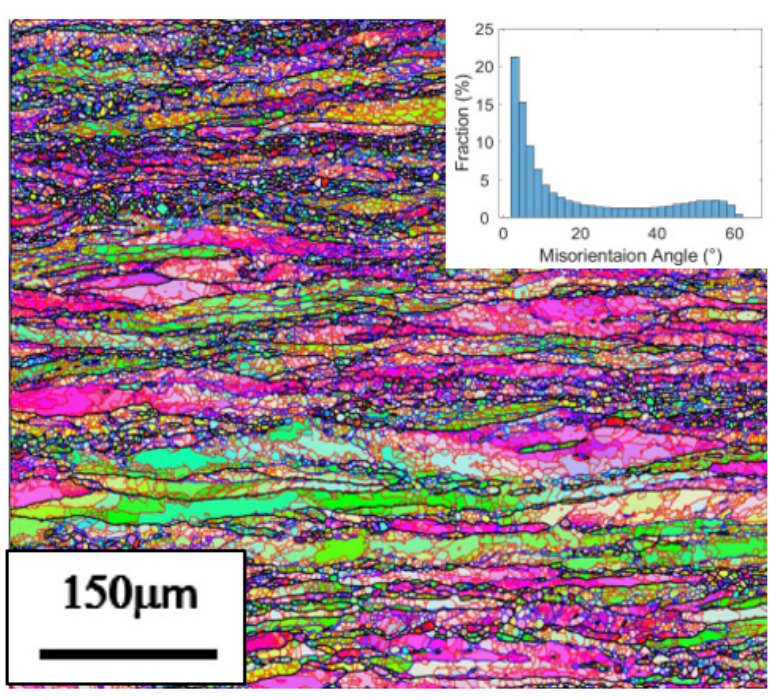

(a)

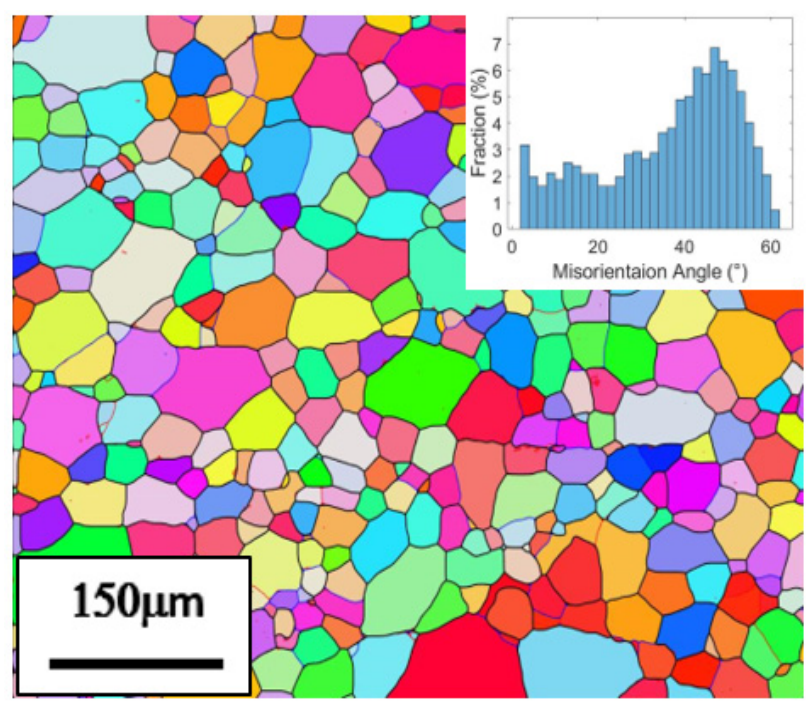

(c)

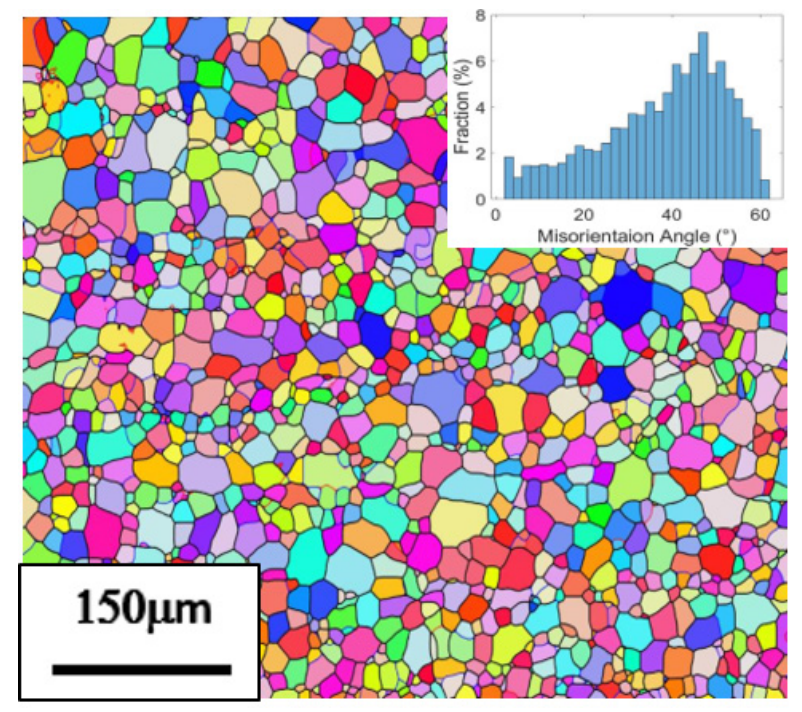

(b)
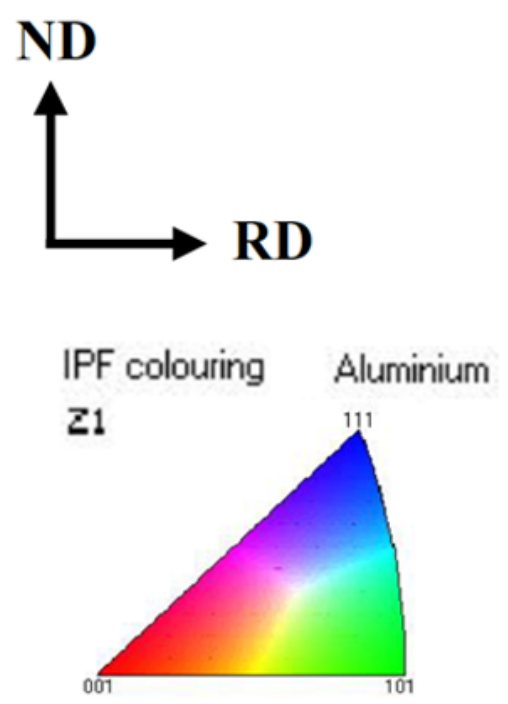

(d)

Figure 3. Grain orientation micrographs and the grain boundary angle bar graph under different annealing processes: (a) alloy A annealed at $250{ }^{\circ} \mathrm{C}$; (b) alloy A annealed at $350{ }^{\circ} \mathrm{C}$; (c) alloy A annealed at $450{ }^{\circ} \mathrm{C}$; (d) IPF (Inverse Pole Figure) coloring map and cross-sectional direction. ND, normal direction; RD, rolling direction. 
Table 2. Recrystallization fraction and microstructures of Al-Mg alloys with various annealing.

\begin{tabular}{|c|c|c|c|c|c|c|c|c|c|c|c|c|}
\hline \multirow[b]{2}{*}{ State Alloy } & \multicolumn{4}{|c|}{$250^{\circ} \mathrm{C}$} & \multicolumn{4}{|c|}{$350^{\circ} \mathrm{C}$} & \multicolumn{4}{|c|}{$450^{\circ} \mathrm{C}$} \\
\hline & $\begin{array}{l}\text { Grain Size } \\
\qquad\left(\mu \mathrm{m}^{2}\right)\end{array}$ & Aspect & R.R. & Result & $\begin{array}{l}\text { Grain Size } \\
\qquad\left(\mu \mathrm{m}^{2}\right)\end{array}$ & Aspect & R.R. & Result & $\begin{array}{l}\text { Grain Size } \\
\qquad\left(\mu \mathrm{m}^{2}\right)\end{array}$ & Aspect & R.R. & Result \\
\hline $\mathrm{A}(0.1 \mathrm{Mn})$ & N.D. & 3.11 & $28 \%$ & Reco. & 243.4 & 1.44 & $88.3 \%$ & C. Recry & 1034.1 & 1.56 & $91.9 \%$ & A. growth \\
\hline $\mathrm{B}(0.1 \mathrm{Zr})$ & N.D. & 4.50 & $26.5 \%$ & Reco. & 221.2 & 1.61 & $67.3 \%$ & P. Recry & 1005.3 & 1.51 & $89.4 \%$ & I. growth \\
\hline $\mathrm{C}(0.05 \mathrm{Sc})$ & N.D. & 3.23 & $19.7 \%$ & Reco. & 152.9 & 1.64 & $41.3 \%$ & P. Recry & 201.2 & 1.55 & $90.8 \%$ & C. Recry \\
\hline
\end{tabular}

N.D.: Non-detectable; R.R.: Recrystallization rate. Reco.: recovery; P.Recry: partially recrystallized; C.Recry: completely recrystallized; I. growth: isotropic growth; A. growth: anisotropic growth.

Alloy $\mathrm{B}(0.1 \mathrm{Zr})$ had no obvious recrystallization when the annealing temperature of the process was $250^{\circ} \mathrm{C}$, which was similar to alloy $\mathrm{A}(0.1 \mathrm{Mn})$. As shown in Figure 3a, most of its grain morphology was a textured crystal structure, so the grain size and aspect ratio could not be effectively calculated. As the annealing temperature reached $350{ }^{\circ} \mathrm{C}$, as shown in Figure $4 \mathrm{a}$, alloy $\mathrm{B}(0.1 \mathrm{Zr})$ was partially recrystallized. However, there was still some textured crystal structure. Its recrystallization rate was $67.1 \%$. The grain size and aspect ratio were $221.2 \mu \mathrm{m}^{2}$ and 1.61, respectively. When the annealing temperature of the process rose to $450{ }^{\circ} \mathrm{C}$, as shown in Figure $4 \mathrm{~b}$, the grain size increased to $1005.3 \mu \mathrm{m}^{2}$, and the grain size grew by $354.5 \%$. The result showed that alloy $\mathrm{B}(0.1 \mathrm{Zr})$ had obvious grain growth, and the growth rate was even higher than that of alloy $\mathrm{A}(0.1 \mathrm{Mn})$. According to the aspect ratio analysis, it can be seen that the alloy aspect ratio dropped to 1.51 . The rate of change was about $-6.2 \%$, indicating that the grain growth was isotropic growth. Compared with that of alloy A, the aspect ratio of alloy B increased by $8.3 \%$, which was obviously different. This phenomenon showed that the crystal grains of Zr-added alloy B had better isotropic growth than Mn-added alloy A.

The microstructure of alloy $\mathrm{C}(0.05 \mathrm{Sc})$ was similar to that of alloy $\mathrm{A}(0.1 \mathrm{Mn})$ when the process was annealed at $250{ }^{\circ} \mathrm{C}$, as shown in Figure 3a. As the temperature rose to $350{ }^{\circ} \mathrm{C}$, most of its grain morphology was still textured crystal structure, as shown in Figure 4c, which contained a large number of sub-grain boundaries and only a few recrystallized grains. Table 2 shows that the recrystallization rate was only $41.3 \%$, and the recrystallized grain size was $125.9 \mu \mathrm{m}^{2}$. When the annealing temperature reached $450{ }^{\circ} \mathrm{C}$, as shown in Figure $4 \mathrm{~d}$, alloy $\mathrm{C}$ was close to complete recrystallization ( $90.5 \%)$ without significant grain growth. This phenomenon explained the fact that the grains of alloy $\mathrm{C}$ inhibited recrystallization better than those of alloys A and B. 


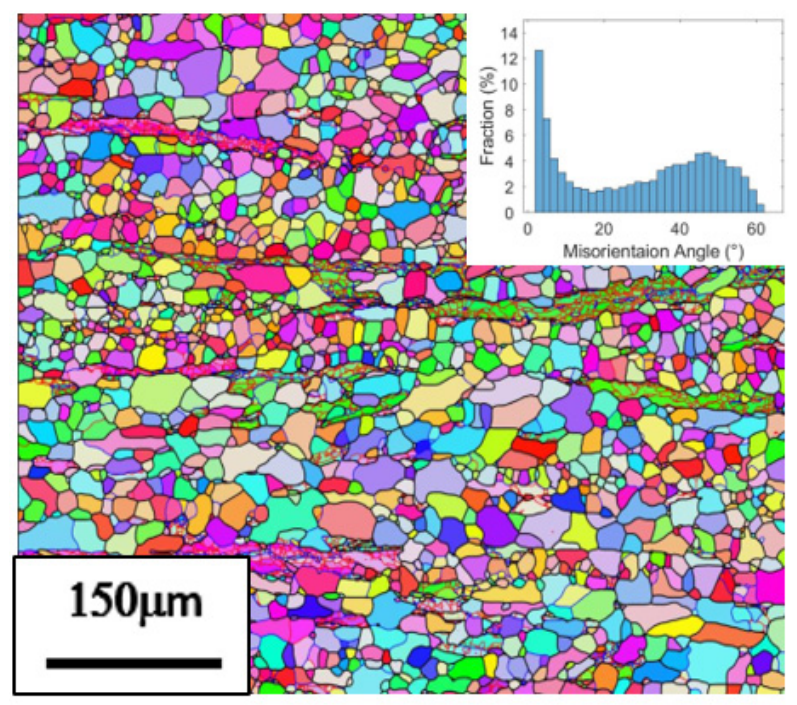

(a)

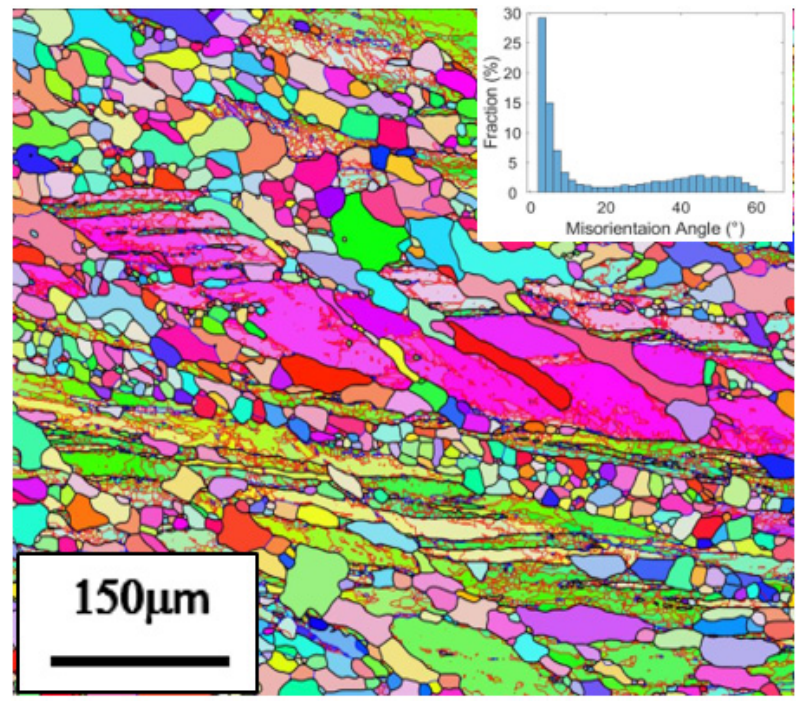

(c)

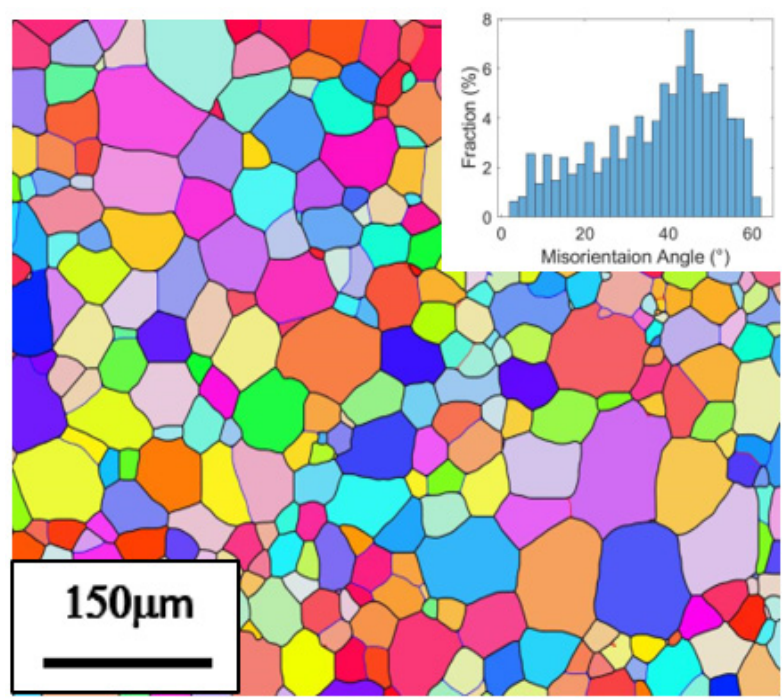

(b)

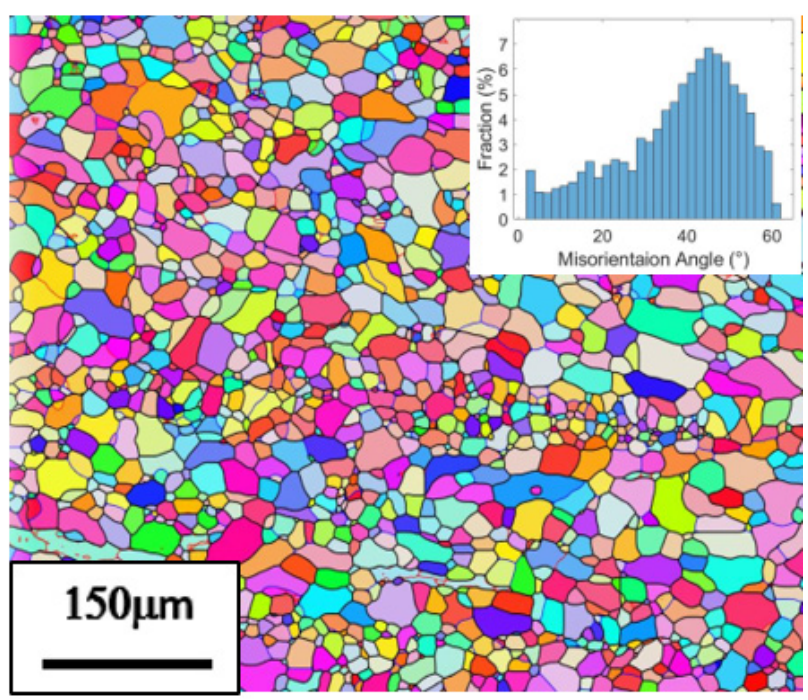

(d)
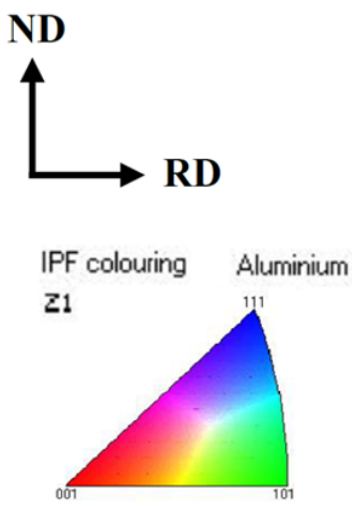

(e)

Figure 4. Grain orientation micrographs and the grain boundary angle bar graph under different annealing processes: (a) alloy B annealed at $350{ }^{\circ} \mathrm{C}$; (b) alloy B annealed at $450{ }^{\circ} \mathrm{C}$; (c) alloy $\mathrm{C}$ annealed at $350{ }^{\circ} \mathrm{C}$; (d) alloy $\mathrm{C}$ annealed at $450{ }^{\circ} \mathrm{C}$; (e) IPF(Inverse Pole Figure) coloring map and cross-sectional direction. ND, normal direction; RD, rolling direction. 


\subsection{TEM Precipitation Analysis}

Figure 5 a shows the TEM image of alloy $\mathrm{A}(0.1 \mathrm{Mn})$ annealed at $350{ }^{\circ} \mathrm{C}$, indicating that there was no intermediate phase in the grains to hinder the dislocation migration. As a result, a new grain boundary occurred. Figure $5 \mathrm{~b}$ shows the $\mathrm{Al}_{6} \mathrm{Mn}$ mesophase of alloy A annealed at $450{ }^{\circ} \mathrm{C}$. Their size exceeded $200 \mathrm{~nm}$ and most of them were distributed on the grain boundary. Thus, it was difficult to hinder the dislocation or sub-grain boundary migration. In other words, Manganese was not a good element to use to inhibit recrystallization.

Figure $5 \mathrm{c}$ shows the TEM image of alloy $\mathrm{B}(0.1 \mathrm{Zr})$ annealed at $350{ }^{\circ} \mathrm{C}$, indicating that $\mathrm{Al}_{3} \mathrm{Zr}$ particles were fine (size: $10-20 \mathrm{~nm}$ ) and densely distributed inside the crystal grains. $\mathrm{Al}_{3} \mathrm{Zr}$ particles were pinning the newly formed sub-grain boundary (TEM shows as diagonal lines), thereby inhibiting recrystallization. When the annealing temperature rose to $450{ }^{\circ} \mathrm{C}$, as shown in Figure $5 \mathrm{~d}$, there were still $\mathrm{Al}_{3} \mathrm{Zr}$ particles inside the grown crystal grains, entangling the dislocation. However, no $\mathrm{Al}_{3} \mathrm{Zr}$ particles were found on the grain boundary, because $\mathrm{Al}_{3} \mathrm{Zr}$ particles began to dissolve on the grain boundary after the annealing temperature exceeded $450{ }^{\circ} \mathrm{C}$ [21]. This phenomenon indicated that during the recrystallization stage, $\mathrm{Al}_{3} \mathrm{Zr}$ particles effectively hindered the dislocation, pinning the sub-grains to postpone recrystallization. However, when the annealing temperature rose above $450{ }^{\circ} \mathrm{C}$, the grain growth occurred, because $\mathrm{Al}_{3} \mathrm{Zr}$ had dissolved on the grain boundary and could not suppress the grain growth.

Figure $5 \mathrm{e}$ is the TEM image of alloy $\mathrm{C}(0.05 \mathrm{Sc})$ annealed at $350{ }^{\circ} \mathrm{C}$, indicating that $\mathrm{Al}_{3} \mathrm{Sc}$ particles were pinning the sub-grain boundary, thus hindering recrystallization. When the annealing temperature rose to $450{ }^{\circ} \mathrm{C}, \mathrm{Al}_{3} \mathrm{Sc}$ particles were still found on the grain boundary of the recrystallized grains, as shown in Figure $5 \mathrm{f}$. This phenomenon indicated that when the alloy started to recrystallize, the Al3Sc particles persisted in pinning the sub-grain, thereby postponing recrystallization. Even when the annealing temperature of the process rose and grain growth was going to occur, $\mathrm{Al}_{3} \mathrm{Sc}$ particles were still pinning the grain boundary, restricting grain growth. Therefore, in both Figures 3 and 5, it can be found that alloy $\mathrm{C}(0.05 \mathrm{Sc})$ not only inhibited recrystallization but was also the only alloy with no obvious grain growth among the three kinds of alloys.

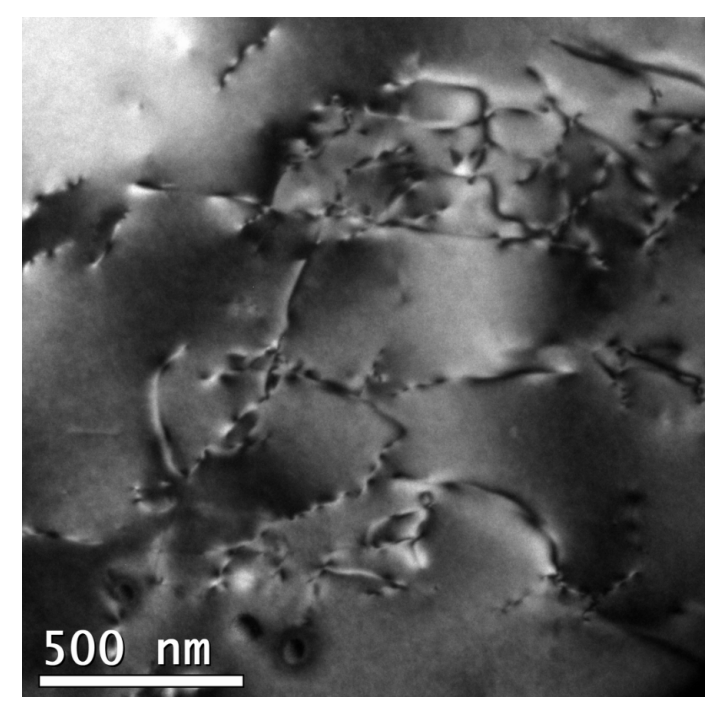

(a)

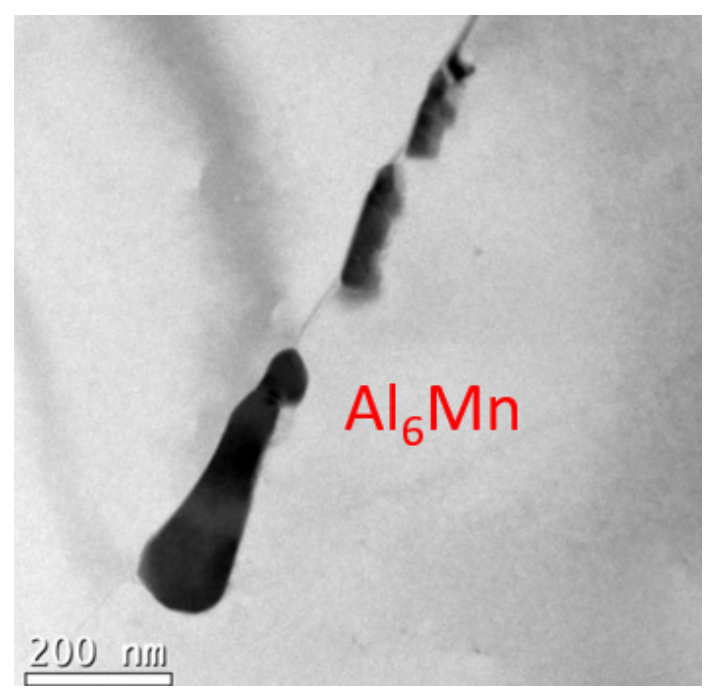

(b)

Figure 5. Cont. 


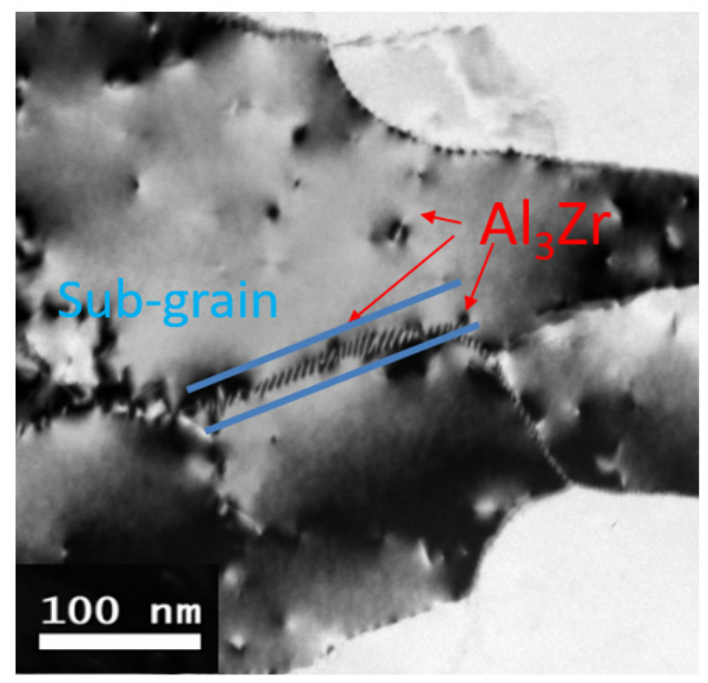

(c)

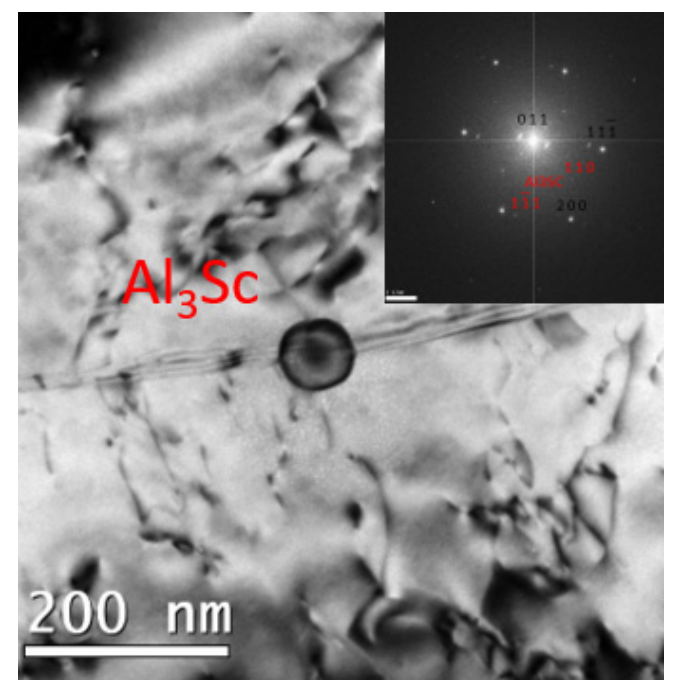

(e)

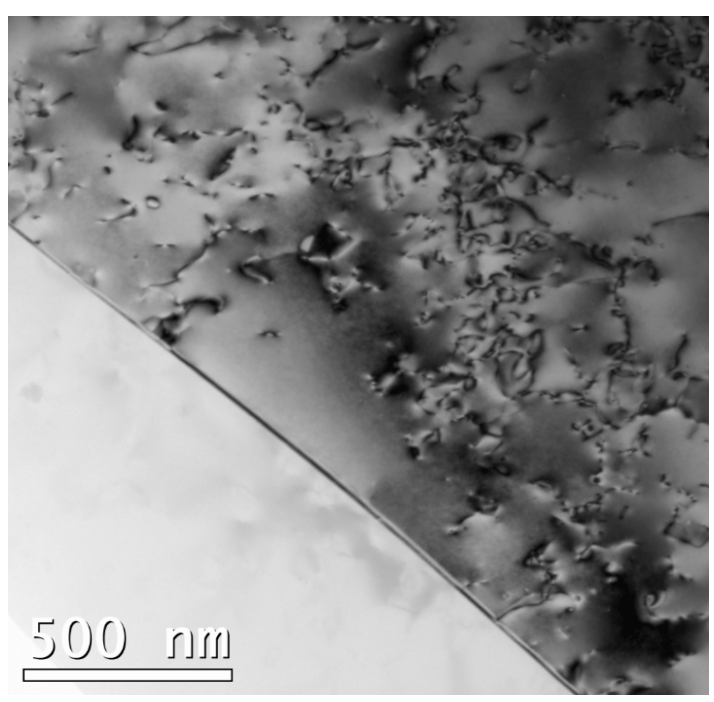

(d)

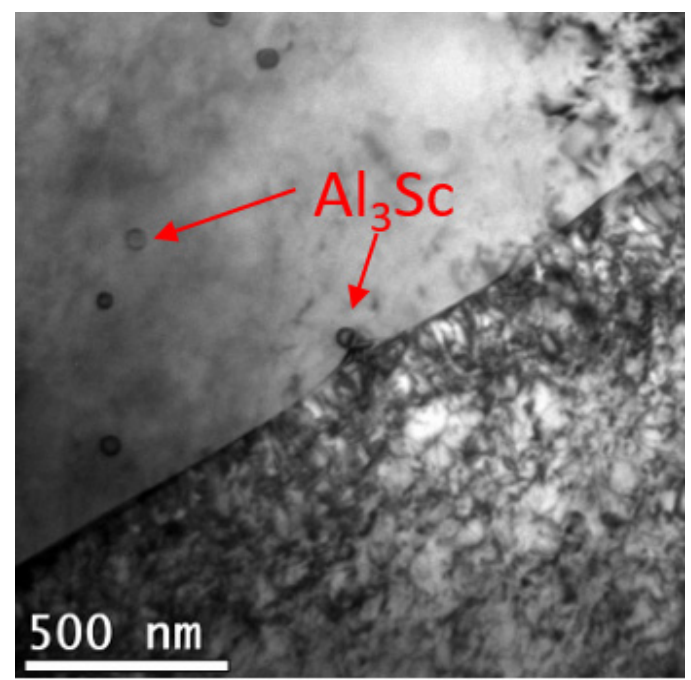

(f)

Figure 5. TEM images of the alloys under different annealing processes: (a) alloy $\mathrm{A}(0.1 \mathrm{Mn})$ annealed at $350{ }^{\circ} \mathrm{C} ;(\mathbf{b}) \mathrm{Al}_{6} \mathrm{MN}$ mesophase of alloy $\mathrm{A}(0.1 \mathrm{Mn})$ annealed at $450{ }^{\circ} \mathrm{C}$ (EDS analysis: $\mathrm{Al}$ : $\left.70.0 \mathrm{wt} \% \mathrm{Mn}: 30.4 \mathrm{wt} \% \mathrm{Mg}: 1.1 \mathrm{wt} \%\right)$; (c) alloy B(0.1Zr) annealed at $350{ }^{\circ} \mathrm{C}$; (d) alloy $\mathrm{B}(0.1 \mathrm{Zr})$ annealed at $450^{\circ} \mathrm{C}$; (e) alloy $\mathrm{C}(0.05 \mathrm{Sc})$ annealed at $350^{\circ} \mathrm{C}$; (f) alloy $\mathrm{C}(0.05 \mathrm{Sc})$ annealed at $450{ }^{\circ} \mathrm{C}$.

\subsection{Corrosion Pproperties}

\subsubsection{Surface Morphology}

Figure 6 shows the SEM images of the $\beta$ phase morphology of alloy $\mathrm{A}(0.1 \mathrm{Mn})$ after sensitization. The $\beta$ phase morphology of alloy $\mathrm{A}(0.1 \mathrm{Mn})$ annealed at $250{ }^{\circ} \mathrm{C}$ is as shown in Figure 6a. From the EBSD images in Figure 3, it can be seen that the three kinds of alloys were not recrystallized, so the $\beta$ phase mainly precipitated on the sub-grain boundary. As the annealing temperature of the alloy A rose to $350{ }^{\circ} \mathrm{C}$, as shown in Figure $6 \mathrm{~b}$, the $\beta$ phase continuously precipitated on the recrystallized grain boundary. When the annealing temperature continued to rise to $450{ }^{\circ} \mathrm{C}$, the recrystallized grains of alloy $\mathrm{A}$ began to grow coarser and the $\beta$ phase began to become discontinuous precipitation on the grain boundary, as shown in Figure 6c. The morphology of the $\beta$ phase changed from continuous precipitation to discontinuous precipitation, which had a significant effect on the improvement of anti-corrosion properties. 


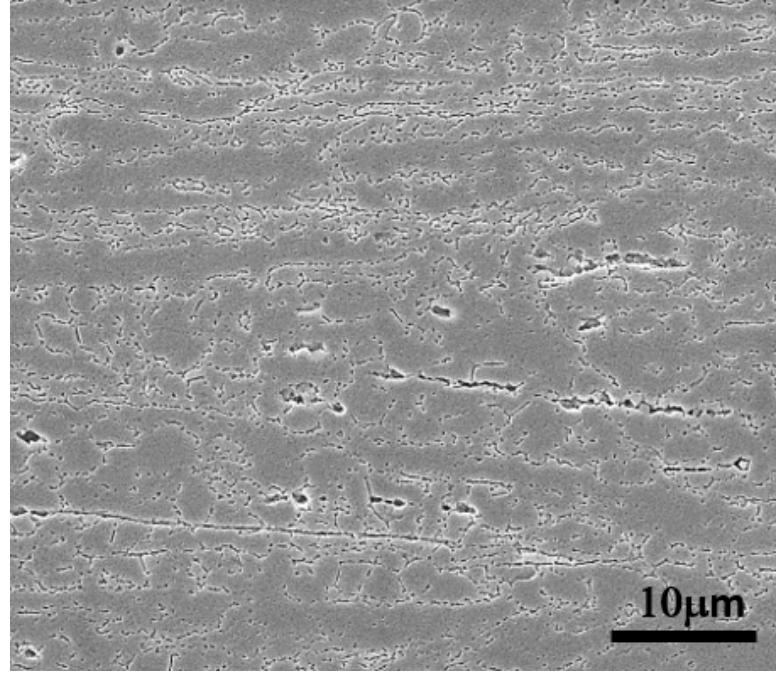

(a)

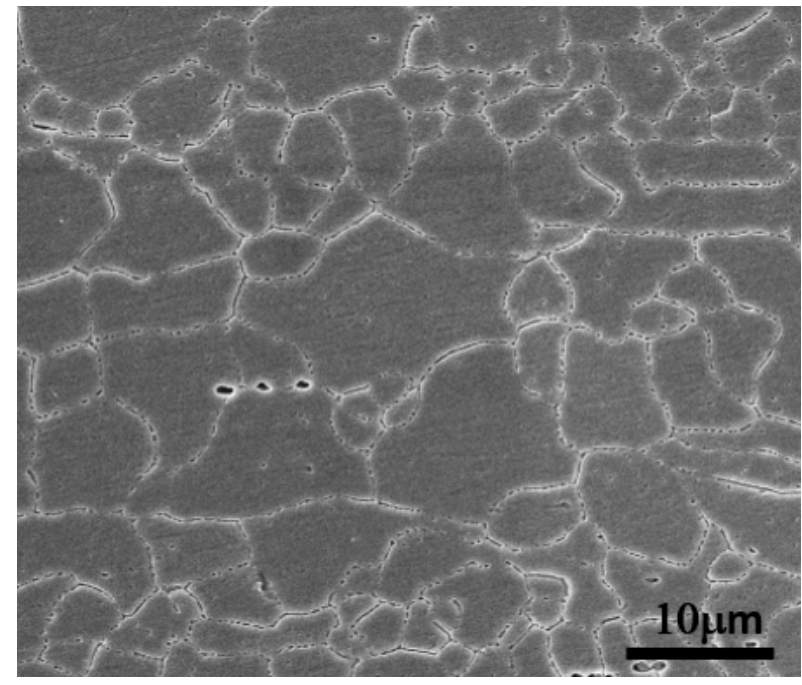

(b)

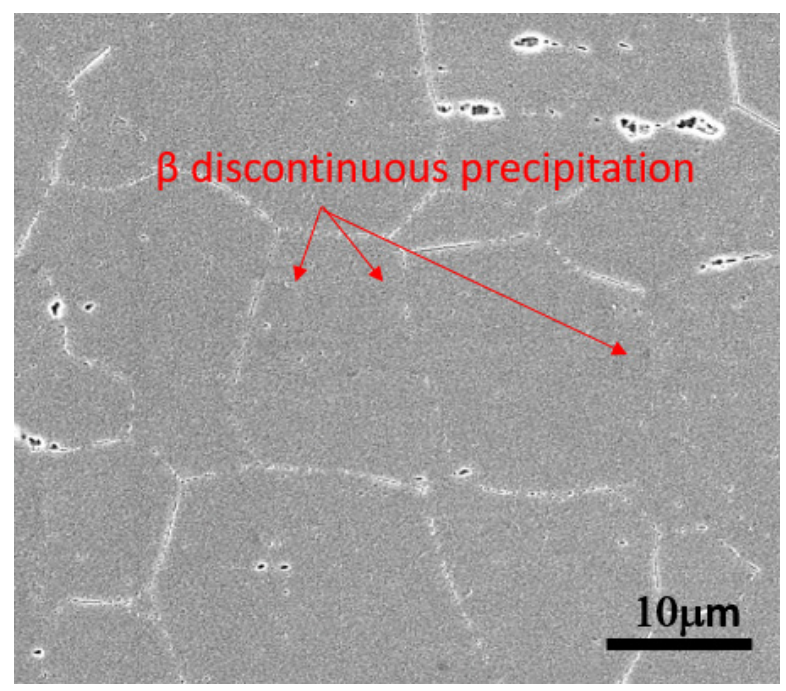

(c)

Figure 6. Precipitation micrographs of $\beta$ phase under different sensitization treatments: (a) alloy $\mathrm{A}(0.1 \mathrm{Mn})$ annealed at $250{ }^{\circ} \mathrm{C}$; (b) alloy $\mathrm{A}(0.1 \mathrm{Mn})$ annealed at $350{ }^{\circ} \mathrm{C}$; (c) alloy $\mathrm{A}(0.1 \mathrm{Mn})$ annealed at $450{ }^{\circ} \mathrm{C}$.

The $\beta$ phase images of alloy $B(0.1 \mathrm{Zr})$ and alloy $\mathrm{C}(0.05 \mathrm{Sc})$ after being annealed at $250{ }^{\circ} \mathrm{C}$ were similar to that of alloy A. As shown in Figure $6 \mathrm{a}$, the $\beta$ phase mainly precipitated on the sub-grain boundary. Figure 7 shows the SEM $\beta$ phase images of alloy $B(0.1 \mathrm{Zr})$ and alloy $\mathrm{C}(0.05 \mathrm{Sc})$ after sensitization. As the annealing temperature of the process increased to $350{ }^{\circ} \mathrm{C}$ for alloy $\mathrm{A}$, as shown in Figure $7 \mathrm{a}$, the $\beta$ phase continuously precipitated on the recrystallized grain boundary. When the annealing temperature continued to rise to $450{ }^{\circ} \mathrm{C}$, the recrystallized grains of alloy A began to coarsen. At this time, the $\beta$ phase began to become discontinuously precipitated on the grain boundary. As shown in Figure $7 \mathrm{~b}$, the morphology of the $\beta$ phase changed from continuous precipitation to discontinuous precipitation, which had a significant effect on the improvement of corrosion resistance.

The EBSD analysis of Figure 3 shows the images of the fine recrystallized grains of alloy $\mathrm{C}(0.05 \mathrm{Sc})$ under the annealing conditions of $350{ }^{\circ} \mathrm{C}$ and $450{ }^{\circ} \mathrm{C}$. The precipitation images of the $\beta$ phase, as indicted in Figure $7 \mathrm{c}, \mathrm{d}$, show continuous precipitation on the recrystallized grain boundaries. 


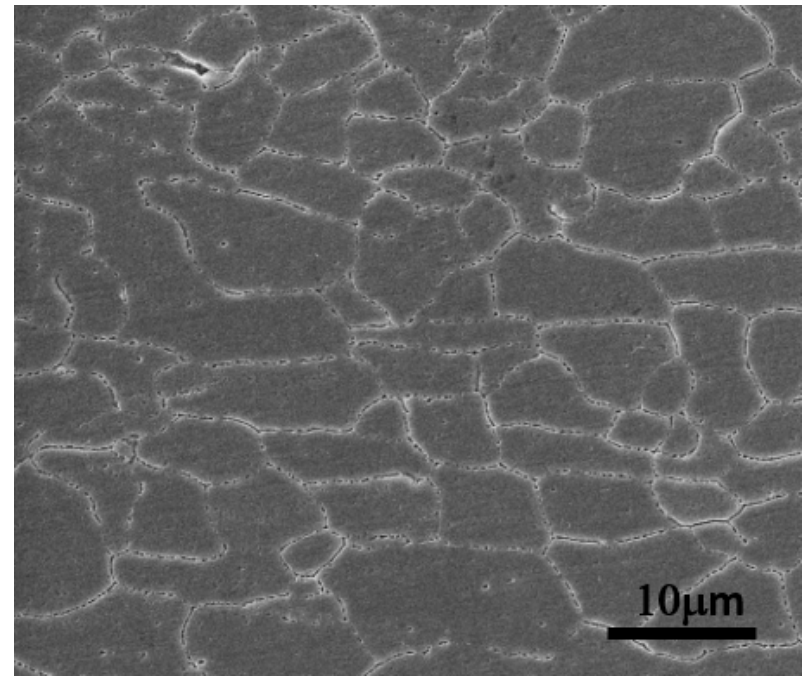

(a)

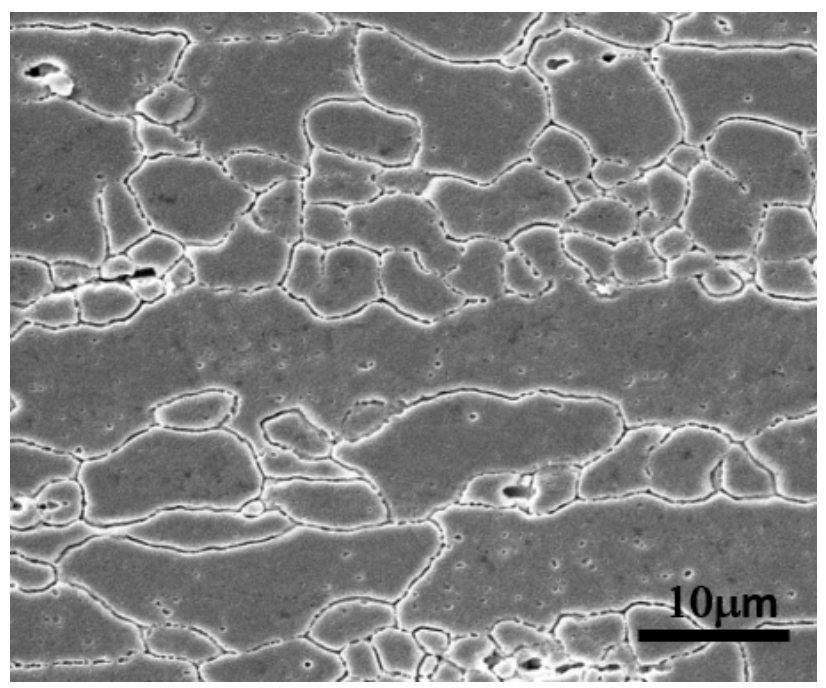

(c)

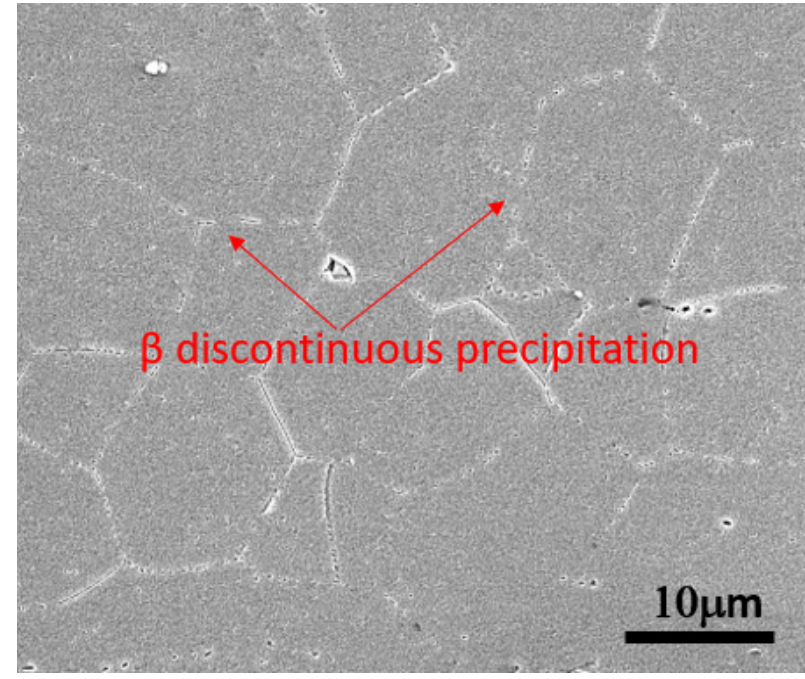

(b)

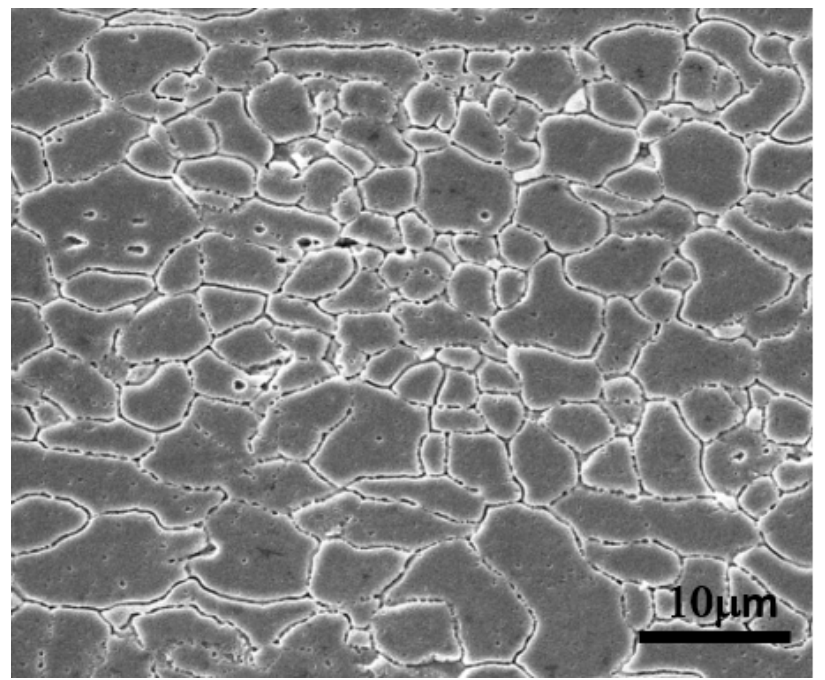

(d)

Figure 7. Precipitation morphology of $\beta$ phase after sensitization treatment: (a) alloy $\mathrm{B}(0.1 \mathrm{Zr})$ annealed at $350{ }^{\circ} \mathrm{C} ;(\mathbf{b})$ alloy $\mathrm{B}(0.1 \mathrm{Zr})$ annealed at $450{ }^{\circ} \mathrm{C}$; (c) alloy $\mathrm{C}(0.05 \mathrm{Sc})$ annealed at $350{ }^{\circ} \mathrm{C}$; (d) alloy $\mathrm{C}(0.05 \mathrm{Sc})$ annealed at $450{ }^{\circ} \mathrm{C}$.

\subsubsection{ASTM G67 NAMLT (Nitric Acid Mass Loss Test)}

The results of ASTM G67 mass loss test of Al-Mg alloys are summarized as shown in Table 3. The data show that as long as the alloy were not sensitized, the corrosion mass loss of the alloy at any annealing temperature was far below $15 \mathrm{mg} / \mathrm{cm}^{2}$ without intergranular corrosion sensitivity (ICS, over $25 \mathrm{mg} / \mathrm{cm}^{2}$ ).

When the annealing temperature of alloy $\mathrm{A}(0.1 \mathrm{Mn})$ was $350{ }^{\circ} \mathrm{C}$ in the process, the alloy began to recrystallize. The corrosion mass loss of the alloy after sensitization was as high as $65.2 \mathrm{mg} / \mathrm{cm}^{2}$. The precipitation morphology of the $\beta-\mathrm{Mg}_{2} \mathrm{Al}_{3}$ phase in Figure 6 shows that the $\beta-\mathrm{Mg}_{2} \mathrm{Al}_{3}$ phase continuously precipitated on the recrystallized grain boundary, which greatly increased the corrosion mass loss. As the annealing temperature rose to $450{ }^{\circ} \mathrm{C}$, recrystallized grains grew. The $\beta-\mathrm{Mg}_{2} \mathrm{Al}_{3}$ phase changed from continuous precipitation to discontinuous precipitation, which reduced the corrosion mass loss of the alloy to 23.0 $\mathrm{mg} / \mathrm{cm}^{2}$.

The precipitation images of the $\beta-\mathrm{Mg}_{2} \mathrm{Al}_{3}$ phase in Figure 7 show the results of the G67 mass loss of alloy $\mathrm{B}(0.1 \mathrm{Zr})$. Its corrosion mass loss trend was the same as that of alloy $\mathrm{A}(0.1 \mathrm{Mn})$. The corrosion properties were worst at the beginning of recrystallization, but gradually became better as the recrystallized grains grew. Figure 4 and Table 2 show that, 
because of the excellent ability of $\mathrm{Al}_{3} \mathrm{Sc}$ phase in alloy $\mathrm{C}(0.05 \mathrm{Sc})$ to inhibit recrystallization, the recrystallized grains of alloy $\mathrm{C}(0.05 \mathrm{Sc})$ did not grow when the process was annealed at $350{ }^{\circ} \mathrm{C}$ to $450{ }^{\circ} \mathrm{C}$. However, this inhibition of recrystallization caused the $\beta-\mathrm{Mg}_{2} \mathrm{Al}_{3}$ phase of the alloy to continuously precipitate after sensitization, resulting in corrosion mass loss that was higher than the standard of intergranular corrosion sensitivity. Thus we found that when the recrystallized grains of the alloy grew, the corrosion mass loss was effectively reduced.

Table 3. ASTM G67 mass loss test of Al-5Mg alloys in annealing and sensitization treatments $\left(\mathrm{mg} / \mathrm{cm}^{2}\right)$.

\begin{tabular}{|c|c|c|c|c|c|c|c|c|c|}
\hline \multirow[b]{2}{*}{ State Alloy } & \multicolumn{3}{|c|}{$250^{\circ} \mathrm{C}$} & \multicolumn{3}{|c|}{$350^{\circ} \mathrm{C}$} & \multicolumn{3}{|c|}{$450^{\circ} \mathrm{C}$} \\
\hline & Annealing & Sensitization & ICS * & Annealing & $\begin{array}{c}\text { Sensitization after } \\
\text { Annealing }\end{array}$ & ICS & Annealing & $\begin{array}{l}\text { Sensitization after } \\
\text { Annealing }\end{array}$ & ICS \\
\hline $\mathrm{A}(0.1 \mathrm{Mn})$ & $1.8(0.2)$ & $24.9(0.9)$ & No & $1.9(0.3)$ & $65.2(2.3)$ & YES & $1.5(0.2)$ & $23.0(0.8)$ & $\mathrm{NO}$ \\
\hline $\mathrm{B}(0.1 \mathrm{Zr})$ & $2.8(0.3)$ & $22.0(1.2)$ & No & $2.3(0.2)$ & $50.3(1.8)$ & YES & $3.1(0.3)$ & $21.5(1.0)$ & $\mathrm{NO}$ \\
\hline $\mathrm{C}(0.05 \mathrm{Sc})$ & $3.2(0.5)$ & $23.6(1.1)$ & No & $3.8(0.4)$ & $58.8(2.2)$ & YES & $3.4(0.2)$ & $59.2(2.5)$ & YES \\
\hline
\end{tabular}

\subsubsection{Corrosion Morphology Analysis}

Figure 8 shows the corrosion morphology of the alloy surface. The corrosion images of alloy $\mathrm{A}(0.1 \mathrm{Mn})$ and alloy $\mathrm{B}(0.1 \mathrm{Zr})$ that began to recrystallize during the process annealing at $350{ }^{\circ} \mathrm{C}$ were mainly intergranular corrosion. Because of severe corrosion damage, the crystal grains obviously peeled off and produced delamination, as shown in Figure 8a,b. As the annealing temperature rose to $450{ }^{\circ} \mathrm{C}$, the corrosion images of alloy $\mathrm{A}(0.1 \mathrm{Mn})$ and alloy $\mathrm{B}(0.1 \mathrm{Zr})$ showed mainly pitting corrosion and some intergranular corrosion after the recrystallized grain growth, as shown in Figure 8c,d. However, alloy $\mathrm{C}(0.05 \mathrm{Sc})$ persisted in the recrystallization stage when the annealing temperature went from $350{ }^{\circ} \mathrm{C}$ to $450{ }^{\circ} \mathrm{C}$. Therefore, its corrosion morphology was mainly intergranular corrosion with lamellar spalling, as shown in Figure 9a,b.

Figure 10 shows an enlarged view of the corrosion surface of alloy $\mathrm{B}(0.1 \mathrm{Zr})$ after sensitization and EPMA mapping. Figure 10a shows the corrosion morphology of alloy $\mathrm{B}(0.1 \mathrm{Zr})$ with serious laminar spalling after annealing at $350{ }^{\circ} \mathrm{C}$. Figure $10 \mathrm{~b}$ shows the EPMA mapping of alloy $\mathrm{B}$ after sensitization; it can be seen that the $\mathrm{Mg}$ element distribution was quite uniform. $\beta-\mathrm{Mg}_{2} \mathrm{Al}_{3}$ phase was widely distributed in the grains and on the grain boundary. Therefore, after the G67 test, the densely and continuously precipitated $\beta$ $\mathrm{Mg}_{2} \mathrm{Al}_{3}$ phase was completely corroded. As a result, the surface microstructure had severe intergranular corrosion and lamellar spalling. Figure 10c shows the corrosion morphology after annealing at $450{ }^{\circ} \mathrm{C}$. The microstructure shows that there was local pitting corrosion on the corroded grains. The EPMA mapping in Figure 10d shows the Mg clusters. This phenomenon indicated that the $\beta-\mathrm{Mg}_{2} \mathrm{Al}_{3}$ phase of the recrystallized grains aggregated and precipitated discontinuously. As a result, the surface microstructure showed local pitting corrosion. 


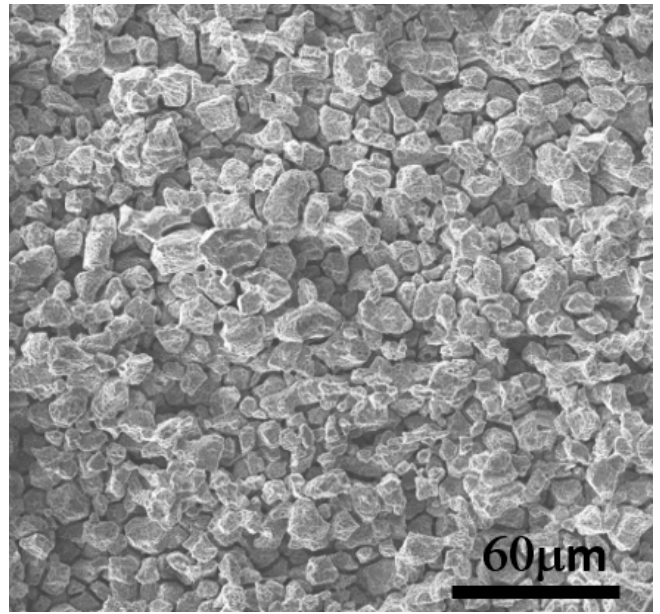

(a)

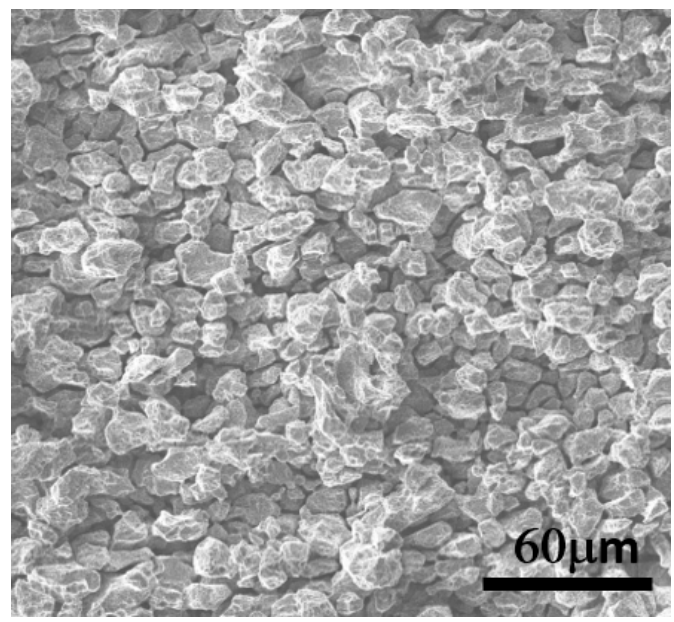

(b)

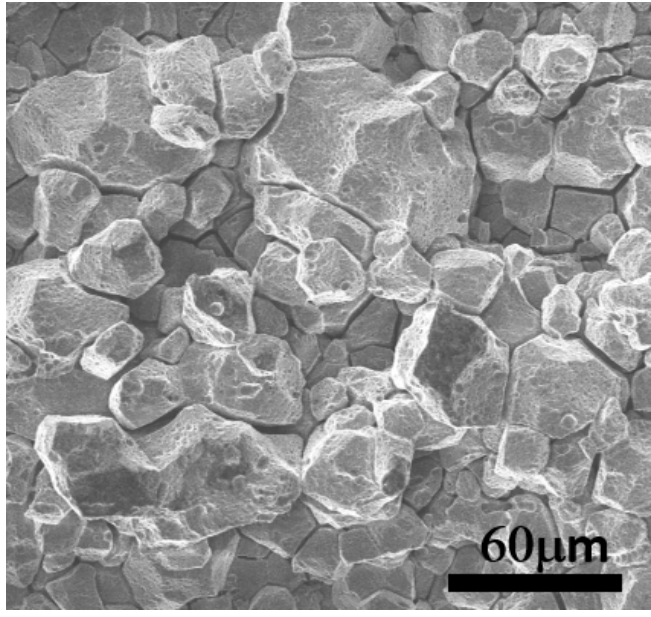

(c)

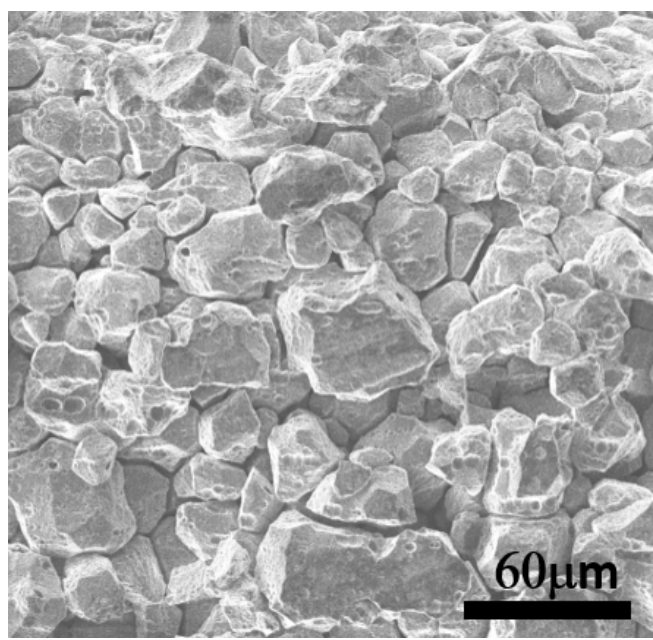

(d)

Figure 8. SEM morphology of alloy corrosion after sensitization: (a) alloy A annealed at $350{ }^{\circ} \mathrm{C}$; (b) alloy B annealed at $350{ }^{\circ} \mathrm{C}$; (c) alloy A annealed at $450{ }^{\circ} \mathrm{C}$; (d) alloy B annealed at $450{ }^{\circ} \mathrm{C}$.

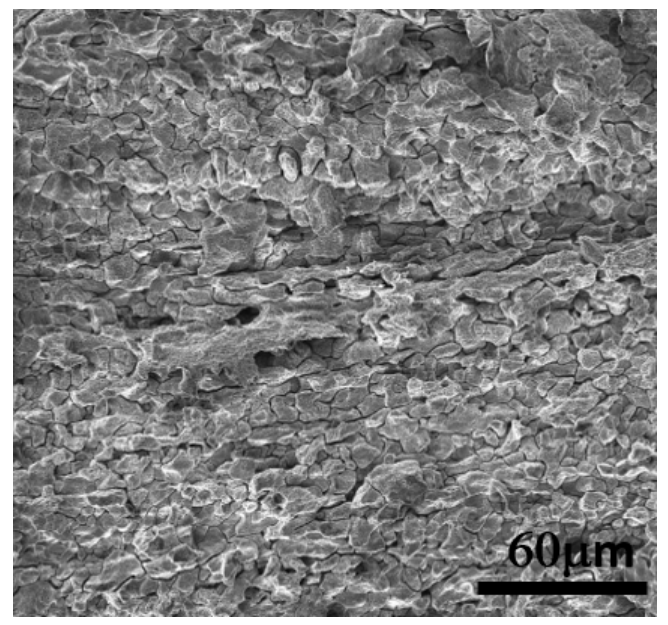

(a)

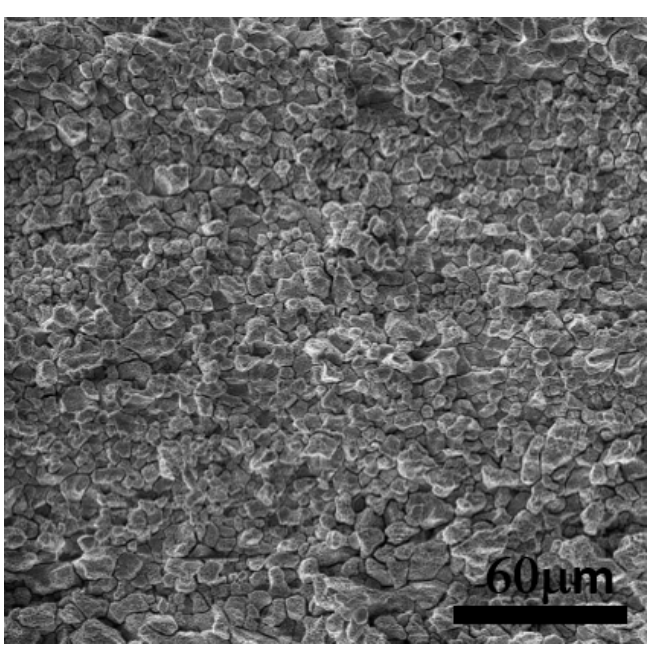

(b)

Figure 9. SEM morphology of alloy corrosion after sensitization: (a) alloy C annealed at $350{ }^{\circ} \mathrm{C}$; (b) alloy $\mathrm{C}$ annealed at $450{ }^{\circ} \mathrm{C}$. 


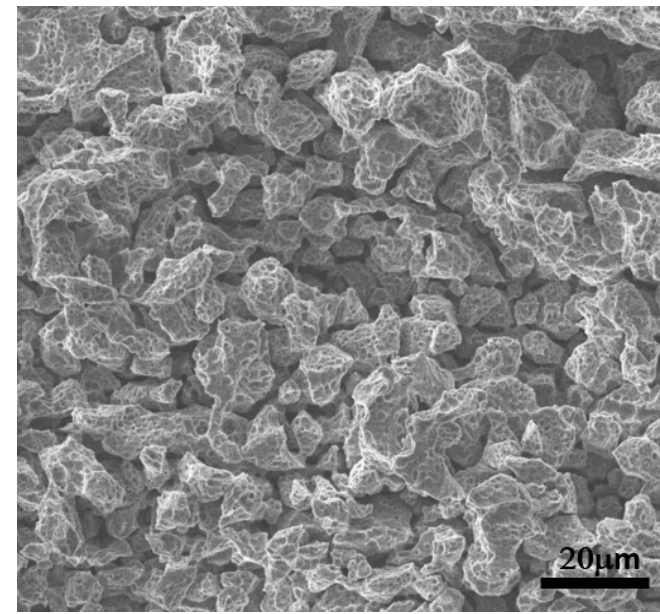

(a)

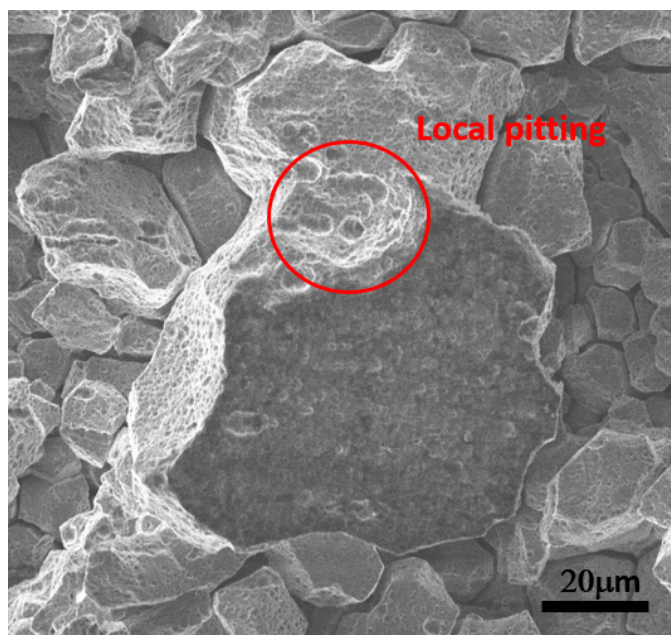

(c)

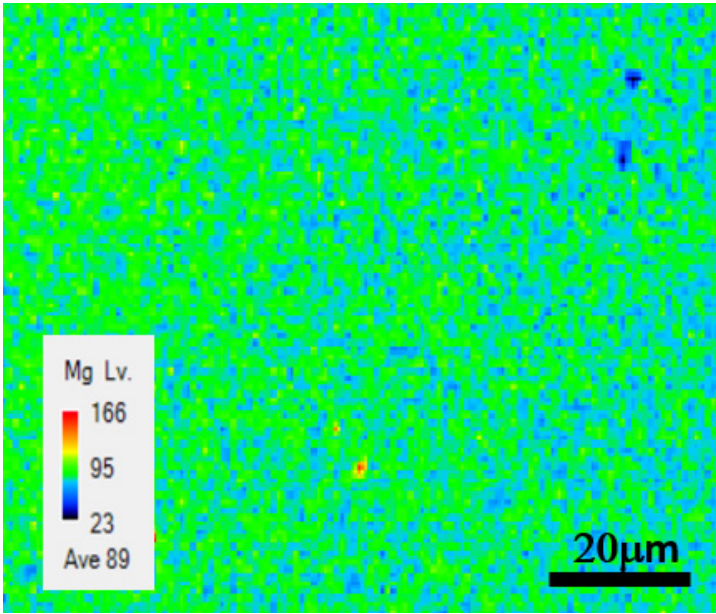

(b)

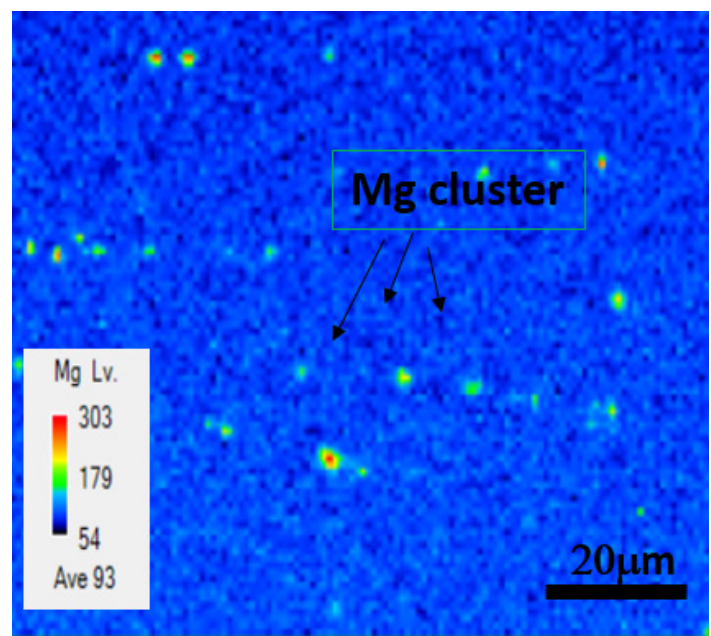

(d)

Figure 10. Alloy $\mathrm{B}\left(0.1 \mathrm{Zr}\right.$ ) after sensitization: (a) SEM morphology of localized surface corrosion when annealed at $350{ }^{\circ} \mathrm{C}$; (b) EPMA mapping of Mg element annealed at $350^{\circ} \mathrm{C}$, (c) SEM morphology of localized surface corrosion when annealed at $450{ }^{\circ} \mathrm{C}$, (d) EPMA mapping of Mg element annealed at $450{ }^{\circ} \mathrm{C}$.

\section{Conclusions}

In this study, trace amounts of manganese, zirconium, and scandium were added to of $\mathrm{Al}-5 \mathrm{Mg}$ alloys investigate their effects on the microstructure and corrosion resistance of the alloys under different recrystallization processes. The results of the study are summarized as follows:

1. After individual process annealing, the high temperature thermally stable dispersed $\mathrm{Al}_{3} \mathrm{Zr}$ and $\mathrm{Al}_{3} \mathrm{Sc}$ phases in the boundary matrices of the $\mathrm{Al}-5 \mathrm{Mg}$ alloys inhibited recrystallization and grain growth. Although $\mathrm{Al}_{3} \mathrm{Zr}$ particles were smaller and denser than $\mathrm{Al}_{3} \mathrm{Sc}$ particles, the dispersed $\mathrm{Al}_{3} \mathrm{Sc}$ particle phase was still better than the $\mathrm{Al}_{3} \mathrm{Zr}$ particle phase in inhibiting the recrystallization and thermal stability.

2. In the initial stage of recrystallization of alloy $\mathrm{A}(0.1 \mathrm{Mn})$ and alloy $\mathrm{B}(0.1 \mathrm{Zr})$, the ASTM G67 mass losses of the two alloys were the most serious. They had serious susceptibility (larger than $25 \mathrm{mg} / \mathrm{cm}^{2}$ ) to intergranular corrosion. However, as the temperature of the process annealing rose to $450{ }^{\circ} \mathrm{C}$, the recrystallized grains began to grow, and the G67 susceptibility to intergranular corrosion obviously decreased (less than $\left.25 \mathrm{mg} / \mathrm{cm}^{2}\right)$. By contrast, though alloy $\mathrm{C}(0.05 \mathrm{Sc})$ could excellently inhibit recrystallization, the ASTM G67 mass loss of alloy C was over $25 \mathrm{mg} / \mathrm{cm}^{2}$, and it became susceptible to intergranular corrosion. 
3. As the temperature of the process annealing rose, The $\beta-\mathrm{Mg}_{2} \mathrm{Al}_{3}$ phase precipitation images of alloy $\mathrm{A}(0.1 \mathrm{Mn}, \mathrm{AA} 5356)$ and alloy $\mathrm{B}(0.1 \mathrm{Zr})$ changed from continuous precipitation to local aggregation. In consequence, the corrosion images of the alloys transformed from intergranular corrosion to local pitting corrosion, thereby improving the corrosion resistance of the alloys.

Whether the recrystallization behavior of $\mathrm{Al}-5 \mathrm{Mg}$ alloy was isotropic grain growth or anisotropic grain growth, its $\beta-\mathrm{Mg}_{2} \mathrm{Al}_{3}$ phase precipitation morphology became discontinuous after sensitization. Therefore, the corrosion morphology of the alloy was local pitting, which had better corrosion resistance. However, if the recrystallization of Al-5Mg alloy was inhibited, grain growth would not occur. As a result, after sensitization, its $\beta-\mathrm{Mg}_{2} \mathrm{Al}_{3}$ phase precipitation morphology was continuous, which caused intergranular corrosion and greatly reduced the corrosion resistance of the alloy.

Author Contributions: Conceptualization, Y.-C.C. and S.-L.L.; methodology, S.-L.L.; software, Y.-C.C. and T.-A.P.; validation, S.-L.L.; formal analysis, Y.-C.C. and T.-A.P.; investigation, Y.-C.C.; resources, S.-L.L.; data curation, Y.-C.C.; writing-original draft preparation, Y.-C.C.; writing-review and editing, S.-L.L.; supervision, S.-L.L.; project administration, Y.-C.C.; funding acquisition, M.-C.C. and Y.-C.C. All authors have read and agreed to the published version of the manuscript.

Funding: The authors gratefully acknowledge the financial support received from the Ministry of Science and Technology (R.O.C) under Contract No. 109-2221-E-008-040-.

Acknowledgments: The authors gratefully acknowledge to C.S. Lin and Y.T. Lee of Instrumentation Center, National Taiwan University for FEG-SEM experiments.

Conflicts of Interest: The authors declare no conflict of interest.

\section{References}

1. Davis, J.R. Aluminum and Aluminum Alloys. In ASM Specialty Handbook; ASM International Materials Park: Novelty, OH, USA, 1994; pp. 33, 59, 61, 580.

2. McMahon, M.E.; Haines, R.L.; Steiner, P.J.; Schulte, J.M.; Fakler, S.E.; Burns, J.T. Beta phase distribution in Al-Mg alloys of varying composition and temper. Corros. Sci. 2020, 169, 108618. [CrossRef]

3. ASTM G67-04 Standard Test Method for Determining the Susceptibility to Intergranular Corrosion of 5XXX Series Aluminum Alloys by Mass Loss After Exposure to Nitric Acid(NAMLT Test). Available online: https:/ /www.asminternational.org/home/- / journal_content/56/33542825/ASTMSTDTESTG0067-04/PUBLICATION-STANDARD-TEMPLATE (accessed on 7 July 2021).

4. Gupta, R.K.; Zhang, R.; Davies, C.H.J.; Birbilis, N. Influence of Mg Content on the Sensitization and Corrosion of Al-xMg(-Mn) Alloys. Corrosion 2013, 69, 1081-1087. [CrossRef]

5. Oguocha, I.N.A.; Adigun, O.J.; Yannacopoulos, S. Effect of sensitization heat treatment on properties of Al-Mg alloy AA5083-H116. J. Mater. Sci. 2008, 43, 4208-4214. [CrossRef]

6. Yan, J.; Hodge, A.M. Study of $\beta$ precipitation and layer structure formation in Al 5083: The role of dispersoids and grain boundaries. J. Alloys Compd. 2017, 703, 242-250. [CrossRef]

7. Tang, Z.; Jiang, F.; Long, M.; Jiang, J.; Liu, H.; Tong, M. Effect of annealing temperature on microstructure, mechanical properties and corrosion behavior of Al-Mg-Mn-Sc-Zr alloy. Appl. Surf. Sci. 2020, 514, 146081. [CrossRef]

8. Scotto, D.A.D.; Gaies, J.; Golumbfskieb, W.; Taheri, M.L. Grain boundary misorientation dependence of $\beta$ phase precipitation in an Al-Mg alloy. Scr. Mater. 2017, 76, 81-84. [CrossRef]

9. Miyake, Y.; Sato, Y.; Teranishi, R.; Kaneko, K. Effect of heat treatments on the microstructure and formability of Al-Mg-Mn-Sc-Zr alloy. Micron 2017, 101, 151-155. [CrossRef]

10. Zhang, R.; Gupta, R.K.; Davies, C.H.J.; Hodge, A.M.; Tort, M.; Xia, K.; FBirbilis, N. The Influence of Grain Size and Grain Orientation on Sensitization in AA5083. Corrosion 2016, 72, 160-168. [CrossRef]

11. Aldalur, E.; Suárez, A.; Veiga, F. Metal transfer modes for Wire Arc Additive Manufacturing Al-Mg alloys: Influence of heat input in microstructure and porosity. J. Mater. Process. Technol. 2021, 297, 117271. [CrossRef]

12. Huang, X.; Baroux, B. Effect of minor Sc on microstructure and mechanical properties of Al-Zn-Mg-Zr alloy metal-inert gas welds. J. Alloys Compd. 2015, 629, 197-207. [CrossRef]

13. Mikhaylovskaya, A.; Mochugovskiy, A.; Levchenko, V.; Tabachkova, N.; Mufalo, W.; Portnoy, V. Precipitation behavior of $\mathrm{L}_{2} \mathrm{Al}_{3} \mathrm{Zr}$ phase in Al-Mg-Zr alloy. Mater. Charact. 2018, 139, 30-37. [CrossRef]

14. Røyset, J.; Ryum, N. Scandium in aluminium alloys. Int. Mater. Rev. 2005, 50, 19-44. [CrossRef]

15. Knipling, K.E.; Seidma, D.N.; Dunand, D.C. Ambient- and high-temperature mechanical properties of isochronally aged Al-0.06Sc, Al-0.06Zr and Al-0.06Sc-0.06Zr (at.\%) alloys. Acta Mater. 2011, 59, 943-954. [CrossRef] 
16. Jiang, J.; Jiang, F.; Zhang, M.; Tang, Z.; Tong, M. Recrystallization behavior of Al-Mg-Mn-Sc-Zr alloy based on two different deformation ways. Mater. Lett. 2020, 265, 127455. [CrossRef]

17. Liu, J.; Yao, P.; Zhao, N.Q.; Shi, C.S.; Li, H.J.; Li, X.; Xi, D.S.; Yang, S. Effect of minor Sc and Zr on recrystallization behavior and mechanical properties of novel Al-Zn-Mg-Cu alloys. J. Alloys Compd. 2016, 657, 717-725. [CrossRef]

18. Goswami, R.; Spanosa, G.; Pao, P.S.; Holtz, R.L. Precipitation behavior of the $\beta$ phase in Al-5083. Mater. Sci. Eng. A 2010, 527, 1089-1095. [CrossRef]

19. Popović, M.; Romhanji, E. Characterization of microstructural changes in an Al-6.8wt.\% Mg alloy by electrical resistivity measurements. Mater. Sci. Eng. A 2008, 492, 460-467. [CrossRef]

20. Wen, W.; Zhao, Y.; Morris, J.G. The Effect of Mg Precipitaion on the Mechanical Properties of 5XXX Aluminum Al-loys. Mater. Sci. Eng. A 2005, 392, 136-144. [CrossRef]

21. Shi, C.; Chen, G. Effect of Zr addition on hot deformation behavior and microstructural evolution of AA7150 aluminum alloy. Mater. Sci. Eng. A 2014, 596, 183-193. [CrossRef]

22. Knipling, K.E.; Dunand, D.C.; Seidman, D.N. Precipitation evolution in Al-Zr and Al-Zr-Ti alloys during isothermal aging at 375-425 ${ }^{\circ}$ C. Acta Mater. 2008, 56, 114-127. [CrossRef]

23. Sun, P.L.; Zhao, Y.H.; Tseng, T.Y.; Suc, J.R.; Lavernia, E.J. The influence of cooling rate on the microstructures and mechanical properties in ultrafine grained aluminum processed by hot rolling. Mater. Sci. Eng. A 2010, 527, 5287-5294. [CrossRef] 